\title{
Efficacy in Emergency Legal Preparedness Underlying the 2014 Ebola Outbreak
}

James G. Hodge Jr.

Leila Barraza

Kim Weidenaar

Alicia Corbett

Gregory Measer

See next page for additional authors

Follow this and additional works at: https://scholarship.law.tamu.edu/lawreview

Part of the Law Commons

\section{Recommended Citation}

James G. Hodge Jr., Leila Barraza, Kim Weidenaar, Alicia Corbett, Gregory Measer \& Asha M. Agrawal, Efficacy in Emergency Legal Preparedness Underlying the 2014 Ebola Outbreak, 2 Tex. A\&M L. Rev. 353 (2015).

Available at: https://doi.org/10.37419/LR.V2.I3.1

This Article is brought to you for free and open access by Texas A\&M Law Scholarship. It has been accepted for inclusion in Texas A\&M Law Review by an authorized editor of Texas A\&M Law Scholarship. For more information, please contact aretteen@law.tamu.edu. 


\section{Efficacy in Emergency Legal Preparedness Underlying the 2014 Ebola Outbreak}

Authors

James G. Hodge Jr., Leila Barraza, Kim Weidenaar, Alicia Corbett, Gregory Measer, and Asha M. Agrawal 


\title{
ARTICLES \\ EFFICACY IN EMERGENCY LEGAL PREPAREDNESS UNDERLYING THE 2014 EBOLA OUTBREAK†
}

\author{
By James G. Hodge, Jr., JD, LLM* \\ Leila Barraza, JD, MPH** \\ Kim Weidenaar, $J D^{* * * *}$ \\ Alicia Corbett, $J D^{* * * * *}$ \\ Gregory Measer***** \\ Asha M. Agrawal******
}

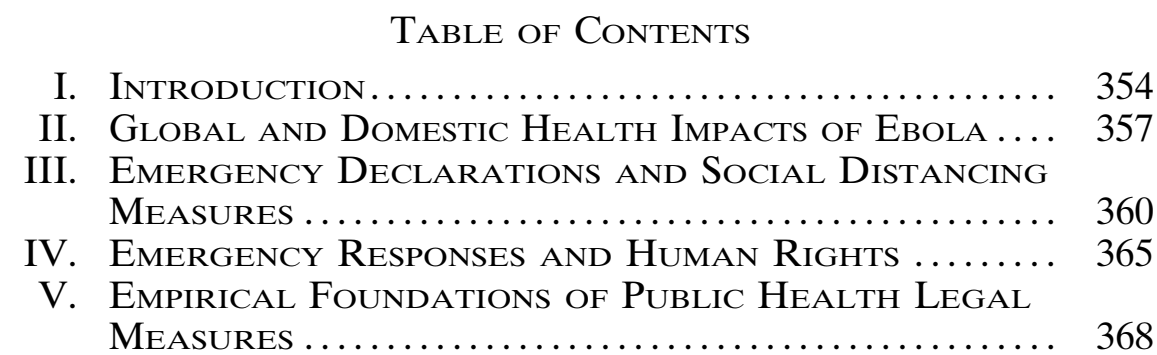

$\dagger$ This Article is based in part on a commentary in the Journal of Law, Medicine, and Ethics and related presentation by James G. Hodge, Jr. on September 23, 2014 at the Sandra Day O'Connor College of Law, Arizona State University ("ASU"). See James G. Hodge, Jr. et al., Global Emergency Legal Responses to the 2014 Ebola Outbreak Public Health and the Law, 42 J.L. Med. \& Ethics 595 (2014). While surveillance data related to the Ebola outbreak are updated through February 11, 2015 , specific analyses of law and policy issues are limited to available information through October 31, 2014. The Authors acknowledge the following individuals for their expert input, research, and editing assistance: Anna Muldoon, MPH, Science Policy Advisor, Assistant Secretary for Preparedness and Response ("ASPR"), U.S. Department of Health and Human Services ("HHS"); Matt Saria and Rose Meltzer at the Sandra Day O'Connor College of Law, ASU; and Andrea Logue at the Mel and Enid Zuckerman College of Public Health, University of Arizona.

* Associate Dean and Professor of Public Health Law and Ethics; Director, Public Health Law and Policy Program; Director, Network for Public Health LawWestern Region Office, Sandra Day O'Connor College of Law, ASU.

** Assistant Professor, Mel and Enid Zuckerman College of Public Health, University of Arizona.

*** Fellow, Public Health Law and Policy Program, Deputy Director, Network for Public Health Law-Western Region Office, Sandra Day O'Connor College of Law, ASU.

**** Of Counsel, Gallagher \& Kennedy, P.A., Phoenix, Arizona; Affiliated Professional, Public Health Law and Policy Program, Sandra Day O'Connor College of Law, ASU.

*****Senior Legal Researcher, Public Health Law and Policy Program, J.D. Candidate (2015), Sandra Day O'Connor College of Law, ASU.

******Senior Legal Researcher, Public Health Law and Policy Program, J.D. Candidate (2016), Sandra Day O'Connor College of Law, ASU.

DOI: https://doi.org/10.37419/LR.V2.I3.1 
A. Case Study 1 - Isolation .................... 369

B. Case Study 2 - Border Closures............... 372

C. Case Study 3 - Lockdown .................... 375

D. Essence of Efficacy of Emergency Public Health Powers................................. 377

VI. Conclusion ............................... 380

\section{INTRODUCTION}

From its relative obscurity over the past three decades, ${ }^{1}$ Ebola viral disease ("EVD") emerged as a substantial global biothreat in 2014 and 2015. The current outbreak of varied strains of Ebola, beginning in March 2014 in Guinea, is projected to impact hundreds of thousands of people ${ }^{2}$ over months, ${ }^{3}$ years, or even indefinitely. ${ }^{4}$ As of October 31, 2014, the spread of EVD was concentrated in several African countries (e.g., Sierra Leone, Liberia, Guinea, and an unrelated outbreak in Democratic Republic of Congo), ${ }^{5}$ with limited additional cases in Nigeria, Senegal, and Mali. Over 2,700 people are known to have died from Ebola in fewer than eight months in Liberia alone; the actual death toll may be far higher. ${ }^{6}$ At one point, the U.S. Centers for Disease Control and Prevention ("CDC") estimated a worst-case scenario of 1.4 million new cases arising largely in already affected countries by early $2015 .^{7}$ Reported cases in the affected regions are considerably less than these estimates, but with a fatality rate hover-

1. Outbreaks Chronology: Ebola Virus Disease, U.S. CTRs. FOR Disease ConTROL \& PREVENTION, http://www.cdc.gov/vhf/ebola/resources/outbreak-table.html \#one (last updated Feb. 5, 2015).

2. Nick Cumming-Bruce \& Alan Cowell, Ebola Could Strike 20,000, World Health Agency Says, N.Y. TIMEs, Aug. 28, 2014, at A7, available at http://www.nytimes .com/2014/08/29/world/africa/ebola-outbreak.html; Sarah Larimer, 20,000 Cases or 100,000? How Researchers Predict Ebola's Spread, WAsh. Post (Sept. 8, 2014), http:// www.washingtonpost.com/news/to-your-health/wp/2014/09/08/20000-cases-or-100000how-researchers-predict-ebolas-spread/.

3. Jon Harper, Dempsey: Ebola Mission Will Probably Last 18 Months, STARs \& STRIPES (Nov. 6, 2014), http://www.stripes.com/news/dempsey-ebola-mission-willprobably-last-18-months-1.312528.

4. Denise Grady, U.S. Scientists See Long Fight Against Ebola, N.Y. Times, Sept. 12, 2014, at A1, available at http://www.nytimes.com/2014/09/13/world/africa/us-scientists-see-long-fight-against-ebola.html?_r=1\&referrer=.

5. 2014 Ebola Outbreak in West Africa, U.S. CTrs. For Disease Control \& Prevention, http://www.cdc.gov/vhf/ebola/outbreaks/2014-west-africa/previous-updates.html (last updated Feb. 6, 2014) [hereinafter U.S. CTRS. FOR DisEASE CONTROL \& Prevention, 2014 Ebola Outbreak in West Africa].

6. Ebola Response Roadmap Situation Report Update, World Health ORG. 2 tbl.1 (2014), http://apps.who.int/iris/bitstream/10665/137592/1/roadmapsitrep_7 Nov2014_eng.pdf?ua $=1$.

7. Questions and Answers: Estimating the Future Number of Cases in the Ebola Epidemic-Liberia and Sierra Leone, 2014-2015, U.S. CTRS. FOR Disease CONTROL \& Prevention, http://www.cdc.gov/vhf/ebola/outbreaks/2014-west-africa/qa-mmwrestimating-future-cases.html (last updated Nov. 19, 2014). 
ing near $50 \%,{ }^{8}$ thousands more West Africans may perish before the end of this current outbreak. ${ }^{9}$

Countering these dire threats are multiple international and regional response efforts fueled by hundreds of millions of relief dollars. Critically-needed supplies are being funneled to West Africa. Thousands of health care workers ("HCWs") from the United States, Europe, China, and Cuba, among other countries, are responding despite significant risks to their own health and safety. ${ }^{10}$ Rapid development and testing of vaccines and treatments are underway. In the interim, an array of existing experimental medications is currently being used or considered on a limited basis. ${ }^{11}$ These interventions may help lower human morbidity and mortality rates related to EVD so long as they are well-timed, efficacious, and ethically allocated.

Yet waiting for a medical panacea or vaccine that may be months or years in the making is not an option when hundreds of people are dying each week throughout West Africa. ${ }^{12}$ Immediate public health responses include declarations of emergencies at the international, national, and regional levels. On August 8, 2014, the World Health Organization ("WHO") declared a public health emergency of international concern. ${ }^{13}$ Several West African nations have also declared formal states of emergency. ${ }^{14}$ Other countries or regions at risk for outbreaks may follow suit. ${ }^{15}$

8. World Health Org., Ebola Virus Disease, West Africa-Update, UN Global Ebola Response (Aug. 28, 2014), http://www.afro.who.int/en/clusters-aprogrammes/dpc/epidemic-a-pandemic-alert-and-response/outbreak-news/4264-ebola -virus-disease-west-africa-28-august-2014.html [hereinafter World Health Org., Ebola Virus Disease, West Africa].

9. Marcelo F.C. Gomes et al., Assessing the International Spreading Risk Associated with the 2014 West African Ebola Outbreak, PLOS Currents: Outbreaks (Sept. 2, 2014), http://currents.plos.org/outbreaks/article/assessing-the-internationalspreading-risk-associated-with-the-2014-west-african-ebola-outbreak/.

10. World Health Org., Ebola Virus Disease, West Africa, supra note 8, at 6.

11. HHS Advances Development of Ebola Vaccine, U.S. DeP't of Health \& Human Servs. (Oct. 16, 2014), http://www.hhs.gov/news/press/2014pres/10/201410 16a.html.

12. Rick Gladstone, W.H.O. Assails Delay in Ebola Vaccine, N.Y. Times, Nov. 3, 2014, at A11, available at http://www.nytimes.com/2014/11/04/world/africa/ebola-curedelayed-by-drug-industrys-drive-for-profit-who-leader-says.html?action $=$ click \& contentCollection $=$ Africa \& region $=$ footer $\&$ module $=$ moreInSection $\& p g$ type $=$ article.

13. Statement on the 1st Meeting of the IHR Emergency Committee on the 2014 Ebola Outbreak in West Africa, World Health Org. (Aug. 8, 2014), http:// www.who.int/mediacentre/news/statements/2014/ebola-20140808/en/.

14. James G. Hodge, Jr., Emergency Legal Preparedness Concerning Ebola: A Primer, Network for Pub. Health L. 8, https://www.networkforphl.org/_asset/dzf8u4/ Ebola-Outbreak-2014---Network-Overview.pdf (last updated Dec. 1, 2014).

15. Abby Phillip, Oxford Study Predicts 15 More Countries Are at Risk of Ebola Exposure, WAsH. Post (Sept. 9, 2014), http://www.washingtonpost.com/news/to-yourhealth/wp/2014/09/09/oxford-study-predicts-15-more-countries-are-at-risk-of-ebolaexposure/. 
Emergency declarations ${ }^{16}$ authorize a profound array of public health measures that create layers of containment designed to curtail infection. Social distancing powers include closures, curfews, isolation, quarantine, travel restrictions, and even lockdowns. ${ }^{17}$ Some of these measures are known to limit the spread of infectious disease. Others are wielded despite little or no proof of their efficacy. In some instances, implementation of these public health emergency powers may even exacerbate the spread of Ebola and lead to other negative health impacts.

Imposing ill-advised, non-efficacious governmental powers in the guise of disease control (1) skews Ebola modeling estimates from WHO, CDC, and others who assume that rates of transmission may diminish as social distancing measures take hold; (2) significantly infringes on civil and human rights, driving epidemics underground; and (3) increases human death tolls from Ebola and other unrelated conditions for which persons may lack access to treatment. Each of these results is untenable.

Clear scientific guidance is needed on the efficacy of legal interventions to protect the public's health during emergencies. Meeting this objective is challenging given the multifarious public health impacts extending from EVD. As documented in Part II, these impacts extend well beyond those suffering from the disease. EVD threatens the health, lives, economy, and security of millions of people in different ways. Public health measures addressing EVD may carry broader, negative public health ramifications. The legal authorities to carry out these public health measures pursuant to emergency declarations are discussed in Part III (and illustrated in Appendix 1). Several West African countries have used multiple public health interventions in an attempt to control Ebola amidst objections and international criticism.

Part IV looks closely at the human rights implications of specific social distancing powers. Potential or actual breaches of human rights to life, health, and access to food, housing, and medical treatments, among other infringements, question the lawfulness of emergency powers that also lack proven efficacy. Building on this theme, Part V explores how use of public health powers in real-time emergencies may negate or derail broader public health outcomes. Three case studies of social distancing powers-isolation, border closure, and lockdown-are presented. The viability and legality of these and other public health measures in response to Ebola are elucidated, followed by a brief conclusion.

16. See, e.g., Gregory Korte, Special Report: America's Perpetual State of Emergency, USA TODAY (Oct. 23, 2014), http://www.usatoday.com/story/news/politics/ 2014/10/22/president-obama-states-of-emergency/16851775/.

17. James G. Hodge, Jr., Public Health law in a Nutshell 93 (2013). 


\section{Global and Domestic Health Impacts of Ebola}

EVD has infected over 22,000 individuals, a majority of whom are women, and has claimed almost 9,000 lives in West Africa (as of February 11, 2015). ${ }^{18}$ CDC Director Tom Frieden likened the health threat from the current outbreak to that caused by HIV/AIDS, which has killed more than 36 million people worldwide since its emergence in the 1980s. ${ }^{19}$ While prior Ebola outbreaks were concentrated largely in rural areas, the disease has made its way in 2014 to impoverished urban areas of West Africa. ${ }^{20}$ Its rapid spread is owed to a "combination of dysfunctional health systems, international indifference, high population mobility, local customs, densely populated capitals, and lack of trust in authorities after years of armed conflict." ${ }^{21}$ EVD has necessitated new approaches involving community training on proper handling of dead bodies to prevent further infection. ${ }^{22}$

HCWs struggle to meet Ebola patients' needs. ${ }^{23}$ Several West African hospitals closed due to a lack of available HCWs to staff them. In Bong County, Liberia, the closure of Phebe Hospital left 330,000 without any emergency hospital facilities. ${ }^{24}$ WHO, CDC, U.S. Department of Defense, Doctors Without Borders, and multiple other entities are attempting to recruit and train hundreds of new HCWs on proper techniques for treating patients while protecting worker

18. Ebola Situation Report 11 February 2015, World Health Org. (Feb. 11, 2015), http://apps.who.int/ebola/en/ebola-situation-report/situation-reports/ebola-situation-report-11-february-2015; Heather Saul, Ebola Crisis: This Is Why '75\%' of Victims Are Women, InDEPENDENT (Aug. 20, 2014), http://www.independent.co.uk/news/ world/africa/ebola-virus-outbreak-this-is-why-75-of-victims-are-women-9681442.html.

19. Elizabeth Chuck, CDC Director on Ebola: 'The Only Thing Like This Has Been AIDS, NBC News (Oct. 9, 2014, 10:29 AM), http://www.nbcnews.com/storyline/ ebola-virus-outbreak/cdc-director-ebola-only-thing-has-been-aids-n222106.

20. David L. Heymann, Commentary, Ebola: Learn from the Past, 514 NATure 299, 299 (2014), available at http://www.nature.com/polopoly_fs/1.16117!/menu/main/ topColumns/topLeftColumn/pdf/514299a.pdf.

21. Jeremy J. Farrar \& Peter Piot, The Ebola Emergency-Immediate Action, Ongoing Strategy, 371 NEw Eng. J. Med. 1545, 1545 (2014), available at http:// www.nejm.org/doi/pdf/10.1056/NEJMe1411471.

22. Sam Smith, Fighting Ebola: "I've Never Experienced Anything Like This," Brit. Red Cross (Oct. 24, 2014), http://blogs.redcross.org.uk/emergencies/2014/10/ fighting-ebola-ive-never-experienced-anything-like/; Tristan McConnell, Some People Would Rather Die of Ebola Than Stop Hugging Sick Loved Ones, Global Post (Oct. 10, 2014, 4:22 PM), http://www.globalpost.com/dispatch/news/health/141010/familescant-mourn-ebola-victims-liberia (Liberia's central facility cremated 30 to 40 bodies a day in October, down from more than 80 bodies a day in September. Still, many individuals remain at risk of infection through handling of the dead.).

23. Betsy McKay \& Drew Hinshaw, Lack of Qualified Staff Hurts Ebola Fight in Africa, WALl ST. J. (Oct. 2, 2014), http://online.wsj.com/articles/lack-of-qualifiedstaff-hurts-ebola-fight-in-africa-1412293011.

24. Colin Freeman, One Patient in a 200-Bed Hospital: How Ebola Has Devastated Liberia's Health System, Telegraph (Aug. 15, 2014, 6:00 PM), http://www.telegraph.co.uk/news/worldnews/ebola/11037365/One-patient-in-a-200-bed-hospital-howEbola-has-devastated-Liberias-health-system.html. 
safety. ${ }^{25}$ Not only is there a lack of trained HCWs, but also personal protective equipment ("PPE"), basic medical supplies, and sanitary water are in short supply. ${ }^{26}$

With limited resources and personnel devoted to EVD responses, additional health threats from cases of malaria, typhoid, and HIV may rise at an alarming rate. In 2012, malaria led to 1,700 deaths in Liberia and an estimated 627,000 deaths worldwide. ${ }^{27}$ Typhoid and paratyphoid fevers killed more than 14,000 in Western Sub-Saharan Africa and 190,242 globally in $2010 .{ }^{28}$ Approximately $68 \%$ of all new HIV cases are reported in Sub-Saharan Africa. ${ }^{29}$ The Ebola outbreak has brought many control efforts for these and other diseases (e.g., measles $)^{30}$ in Liberia, Sierra Leone, and Guinea to a standstill. ${ }^{31}$ Spikes in the infection rates of these conditions in the aftermath of Ebola may constitute the next public health crisis in these regions.

Children arguably suffer most during outbreaks. ${ }^{32}$ Routine vaccination programs have been completely halted or severely reduced, leading to potential deaths from vaccine-preventable diseases. ${ }^{33}$ While infant mortality rates in Liberia, Sierra Leone, and Guinea have declined in recent years, ${ }^{34}$ pregnant women lack access to medical cen-

25. McKay \& Hinshaw, supra note 23.

26. Sarah Boseley, Ebola Crisis-The Guardian Briefing, Guardian (Oct. 31, 2014), http://www.theguardian.com/world/2014/sep/25/-sp-ebola-crisis-briefing; Josh Harris, Shortage of Engineers and Sanitation Experts Risk Undermining Efforts to Halt Ebola Virus in West Africa, Warns International Medical Corp., InT'L Med. CoRPS UK (Oct. 8, 2014), http://www.internationalmedicalcorps.org.uk/shortage-engineers-sanitation-experts-risks-undermining-efforts-halt-ebola-virus-outbreak-westafrica-warns-international-medical-corps/.

27. World Malaria Report, World Health Org. ix. 149 (2013), http:// www.who.int/malaria/publications/world_malaria_report_2013/report/en/.

28. GBD Data, Typhoid in Western Sub-Saharan Africa \& Globally, Inst. For Health Metrics \& Evaluation (2014), http://www.healthdata.org/search-gbddata?s=typhoid \%20Western\%20Sub-Saharan\%20Africa.

29. The Global HIV/AIDS Epidemic, Kaiser Family Found. (Dec. 1, 2014), http://kff.org/global-health-policy/fact-sheet/the-global-hivaids-epidemic. See also Liberia, HIV and AIDS Estimates, UNAIDS (2013), http://www.unaids.org/en/regionscountries/countries/liberia.

30. Guidance for Immunization Programmes in the African Region in the Context of Ebola, World Health Org. (Oct. 24, 2014), http://www.measlesrubellainitiative.org/wp-content/uploads/2014/10/Immunization_and_Ebola_Version _Oct_24_2014.pdf [hereinafter Guidance].

31. Ericka Check Hayden, Ebola Obstructs Malaria-Control, 514 Nature 15, 15, available at http://www.nature.com/polopoly_fs/1.16029!/menu/main/topColumns/top LeftColumn/pdf/514015a.pdf.

32. Sheri Fink, Ebola's Mystery: One Boy Lives, Another Dies, N.Y. Times, Nov. 10, 2014, at A1, available at http://www.nytimes.com/2014/11/10/world/africa/the-capri cious-hand-of-ebola-one-boy-survives-as-others-die.html?action=click\&content Collection $=$ health \&region $=$ footer $\&$ module $=$ moreInSection $\&$ pgtype $=$ article\&_r $=0$.

33. Lisa Schlein, Ebola Has Devastating Impact on Children in Liberia, VoICE oF AmericA (Sept. 12, 2014, 11:18 PM), http://www.voanews.com/content/ebola-hasdevastating-impact-on-children-in-liberia/2448520.html; Guidance, supra note 30.

34. At a Glance: Liberia, UNICEF, http://www.unicef.org/infobycountry/liberia _2513.html (last updated May 25, 2012); At a Glance: Sierra Leone, UNICEF, http:// 
ters to deliver their babies due to closures or unavailability of space. ${ }^{35}$ In the weeks ahead, this lack of access may increase infant mortality rates. $^{36}$ Young children are also orphaned at a distressing rate due to Ebola deaths among their parents or caregivers. ${ }^{37}$

Collateral impacts of Ebola in West Africa are equally significant. Agricultural production, tourism, mining, and service industries are all diminished in the affected regions. ${ }^{38}$ Border closures have halted commercial activities ${ }^{39}$ and limited food supplies. ${ }^{40}$ Food prices have increased an average of $24 \%$ in Liberia, Guinea, and Sierra Leone, making available food unattainable for many. ${ }^{41}$ Markets emptied as government restrictions and fears of infection led people to avoid congregating. ${ }^{42}$ Labor shortages rose as workers became ill or took care of ill relatives. ${ }^{43}$ Deaths among farmers may leave fields fallow and threaten immediate food supplies. ${ }^{44}$ An estimated 750,000 West Afri-

www.unicef.org/infobycountry/sierraleone_statistics.html (last updated Dec. 27, 2013); At a Glance: Guinea, UNICEF, http://www.unicef.org/infobycountry/guinea_statistics.html (last updated Dec. 26, 2013).

35. Ebola Effect Reverses Gains in Maternal, Child Mortality, InTEGRATED ReG'L INFO. NeTwORKs (Oct. 8, 2014), http://www.irinnews.org/report/100698/ebola-effectreverses-gains-in-maternal-child-mortality.

36. See id.

37. Debora Patta, Ebola Orphans of Liberia, CBS News (Oct. 20, 2014, 7:15 PM), http://www.cbsnews.com/news/finding-hope-after-being-orphaned-by-ebola; Adam Balles, Ebola Orphanage Opens in Sierra Leone, Voice of America (Oct. 20, 2014, 1:50 PM), http://www.voanews.com/content/ebola-orphanage-opens-in-sierra-leone/ 2489944.html.

38. Amadou Sy \& Amy Copley, Understanding the Economic Effects of 2014 Ebola Outbreak in West Africa, Brookings (Oct. 1, 2014, 3:41 PM), http:// www.brookings.edu/blogs/africa-in-focus/posts/2014/10/01-ebola-outbreak-west-africa -sy-copley; The Cost of a Pandemic Ebola's Economic Impact, Economist (Sept. 3, 2014, 7:19 PM), http://www.economist.com/blogs/baobab/2014/09/costs-pandemic.

39. Marcelo Giugale, The Economic Impact of Ebola, World Post (Oct. 8, 2014, 9:00 AM), http://www.huffingtonpost.com/marcelo-giugale/the-economic-impact-ofeb_b_5951458.html.

40. Unprecedented Modern Famine to Follow Ebola Outbreak, CNBC AFr. (Oct. 22, 2014, 7:17 PM), http://www.cnbcafrica.com/video/?bctid=3852145499001; Caelainn Hogan, Groups Rush to Prevent Food Crisis in Ebola-Stricken Areas, WAsh. Post, Aug. 28, 2014, at A11, available at http://www.washingtonpost.com/national/healthscience/groups-rush-to-avoid-food-crisis-in-ebola-stricken-areas/2014/08/27/80285e8a2d3d-11e4-994d-202962a9150c_story.html [hereinafter Hogan, Groups]; Adam Nossiter, Ebola is Taking a Second Toll, on Economies, N.Y. TIMEs, Sept. 6, 2014, at A1, available at http://www.nytimes.com/2014/09/06/world/africa/ebola-hurting-african -economies.html?_r=0.

41. Stephanie Nebehay \& James Harding Giahyue, Food Prices Soar in Ebola-Hit Countries, Aid Workers Deliver Rations, ReuTERs (Oct. 17, 2014, 1:49 PM), http:// www.reuters.com/article/2014/10/17/us-health-ebola-westafrica-idUSKCN0I61E7201 41017.

42. $I d$.

43. Garrett Ingoglia, A Firsthand Account of Life at the Epicenter of the Ebola Outbreak in Monrovia, Liberia, World Post (Oct. 9, 2014, 10:45 AM), http:// www.huffingtonpost.com/garrett-ingoglia/a-firsthand-account-of-li_b_5958884.html.

44. Hogan, Groups, supra note 40. 
cans are at risk of famine or death from malnutrition. ${ }^{45}$ According to the World Bank's Ebola Impact Index, the total economic impact of EVD could exceed $\$ 32$ billion by the end of 2015 if the virus spreads to neighboring countries in West Africa. ${ }^{46}$

\section{Emergency Declarations and Social Distancing Measures}

Against this backdrop is the need to address the social and economic consequences of Ebola in West Africa and abroad through a series of legal preparedness efforts to stem its spread. Formal emergency declarations alter the legal environment to facilitate public health and medical responses, ${ }^{47}$ instantly allowing measures that might otherwise require considerable legal maneuvering absent a declaration.

Per Appendix 1, Ebola-related Emergency Measures in Select Countries, governments in Guinea, Liberia, Nigeria, and Sierra Leone declared emergencies that collectively impact nearly 200 million people. ${ }^{48}$ The declarations differ in form, content, duration, and substance, but each authorizes an array of flexible powers and corresponding measures to address the public health impact of Ebola. For example, each government may close schools, businesses, roads, or borders. Liberia closed government offices, placing workers on leave for thirty days to contain the spread of EVD. ${ }^{49}$ Sierra Leone declared a national "stay at home" day for reflection, education, and

45. Connor Adams Sheets, Ebola Epidemic 2014: Liberians Threaten to Break Quarantine Over Food Shortage, InT'L Bus. Times (Oct. 23, 2014, 3:32 PM), http:// www.ibtimes.com/ebola-epidemic-2014-liberians-threaten-break-quarantine-overfood-shortage-1711614.

46. The Economic Impact of the 2014 Ebola Epidemic: Short and Medium Term Estimates for West Africa, ThE WORLd BANK GrP. 3 (Oct. 7, 2014), http://wwwwds.worldbank.org/external/default/WDSContentServer/WDSP/IB/2014/10/07/00045 6286_20141007140300/Rendered/PDF/912190WP0see0a00070385314B00PUBLIC

0.pdf; Maryla Maliszewska, Ebola's Economic Damage to Africa: How Much? How Long?, WORLD BANK (Oct. 9, 2014), http://blogs.worldbank.org/developmenttalk/ ebola-s-economic-damage-africa-how-much-how-long; Max Ehrenfreund, Fear of Ebola Could Have "Catastrophic" Economic Costs, World Bank Predicts, Wash. Post (Oct. 8, 2014), http://www.washingtonpost.com/blogs/wonkblog/wp/2014/10/08/ fear-of-ebola-could-have-catastrophic-economic-costs-world-bank-predicts/.

47. James G. Hodge, Jr. \& Evan D. Anderson, Principles and Practice of Legal Triage During Public Health Emergencies, 64 N.Y.U. AnN. Surv. Am. L. 249, 250 (2008).

48. The World FactBook, U.S. Cent. Intelligence Agency, https:// www.cia.gov/library/publications/the-world-factbook/rankorder/2119rank.html (last visited Oct. 30, 2014).

49. Ellen Johnson Sirleaf, President of Liber., Special Statement by President Ellen Johnson Sirleaf on Additional Measures in the Fight Against the Ebola Virus Disease (July 30, 2014), available at http://www.emansion.gov.lr/doc/Special_State _Delivered_July\%2030.pdf [hereinafter Sirleaf, Statement on Additional Measures]. 
prayer. ${ }^{50}$ Nigeria ordered all schools to remain closed for forty-three days beyond the usual summer vacation. ${ }^{51}$ Guinea closed all schools and universities indefinitely until measures aimed at controlling Ebola transmission took effect. ${ }^{52}$

Each country also implemented stringent screening, surveillance, testing, and treatment measures, including widespread airport-screening procedures to evaluate passenger temperatures and symptoms. Nigeria screened all passengers arriving by air and sea in Lagos and Rivers State and retooled its polio eradication technology and infrastructure to trace contacts of initial Ebola cases. ${ }^{53}$ These combined procedures are credited with the containment of initial cases of Ebola in Lagos. ${ }^{54}$ Though purposeful, such measures are imperfect due to the epidemiology of the disease and limitations of available tests. As Ebola is only detectable and transmissible among symptomatic persons, asymptomatic persons, like Thomas Eric Duncan who left Liberia for Dallas, Texas, in late September 2014, can still slip through the cracks. ${ }^{55}$ Without an accurate, rapid test for the presence of EVD ${ }^{56}$ it takes hours to confirm that someone is infectious. ${ }^{57}$

While Nigeria was declared "Ebola free," resource limitations and other factors present substantial public health challenges to the re-

50. Adam Nossiter, Sierra Leone Deploys Troops in Ebola Crisis, N.Y. Times, Aug. 5, 2014, at A4, available at http://www.nytimes.com/2014/08/06/world/africa/ sierra-leone-deploys-troops-in-ebola-crisis.html.

51. Ebola Outbreak: Nigeria Closes All Schools Until October, BBC News Afr. (Aug. 27, 2014), http://www.bbc.com/news/world-africa-28950347. Classes resumed in several Nigerian states on October 8,2014, but some teachers refused to work until back salaries were paid and adequate preventive measures were implemented. Amaka Abayomi et al., Ebola: Finally, 10 States Resume Nationwide, VANGUARD (Oct. 9, 2014, 12:22 AM), http://www.vanguardngr.com/2014/10/ebola-finally-10states-resume-nationwide/.

52. The Associated Press, Guinea: Schools Reopen as Ebola Ebbs, N.Y. Times (Jan. 19, 2015), http://www.nytimes.com/2015/01/20/world/africa/guinea-schools-reopen-as-ebola-ebbs.html (Schools in Guinea began reopening on January 19, 2015); see Guinea, INT'L SOS, https://web.archive.org/web/20141113180011/ (last visited Feb. 11, 2015) (accessed by searching for INTERNATIONAL SOS in the Internet Archive Index).

53. Nigeria is Now Free of Ebola Virus Transmission, World Health Org. (Oct. 20, 2014), http://www.who.int/mediacentre/news/ebola/20-october-2014/en/ [hereinafter Nigeria Free of Ebola].

54. Id. WHO Director Margaret Chan concluded as a result that "any country in the world experiencing an imported case can hold onward transmission to just a handful of cases." Id.

55. Isaac I. Bogoch, Assessment of the Potential for International Dissemination of Ebola Virus via Commercial Air Travel During the 2014 West African Outbreak, 385 LANCET 29, 30 (2015), available at http://www.thelancet.com/pdfs/journals/lancet/ PIIS0140-6736(14)61828-6.pdf.

56. Andrew Pollack, Researchers Seek Crucial Tool: A Fast, Finger-Prick Ebola Test, N.Y. Times, Nov. 5, 2014, at B2, available at http://www.nytimes.com/2014/11/05/ business/ebola-researchers-rush-to-find-a-fast-diagnostic-test.html?action=CLick \& contentCollection $=$ us $\% 20$ Open $\&$ region $=$ article \& module $=$ promotron.

57. Donald G. McNeil, Jr., Ask Well: Ebola Testing for All New Arrivals?, N.Y. TIMEs (Oct. 25, 2014), http://well.blogs.nytimes.com/2014/10/25/ask-well-ebola-testing -for-all-new-arrivals/. 
maining affected West African countries. Facing thousands of active cases of Ebola, governmental authorities in Liberia ${ }^{58}$ and Sierra Leone $^{59}$ have instituted fourteen of the fifteen emergency measures listed in Appendix 1 including:

1. mandatory disinfection of all public facilities;

2. prohibitions on price increases;

3. waivers of import duties for certain sanitation products;

4. isolation of infected persons or quarantine of those exposed;

5. restrictions on public meetings and gatherings;

6. increasing surveillance and house-to-house searches;

7. border closures and travel curfews; and

8. lockdowns of entire communities.

Many of these measures may be considered extreme depending on the duration of emergency declarations, which can last for as few as ninety days (e.g., Liberia) ${ }^{60}$ or indefinitely (e.g., Guinea). ${ }^{61}$

Though expansive, these interventions are constitutionally authorized in most nations affected by Ebola. Sierra Leone's constitution allows the President to "take such measures as appear ... necessary or expedient for the purpose of maintaining and securing peace, order and good government" during a public emergency. ${ }^{62}$ Constitutions in

58. Sirleaf, Statement on Additional Measures, supra note 49.

59. Ernest Bai Koroma, President of Sierra Leone, Address to the Nation on the Ebola Outbreak by His Excellency the President Dr. Ernest Bai Koroma (July 30, 2014), available at http://www.statehouse.gov.sl/index.php/component/content/article/ 34-news-articles/925-address-to-the-nation-on-the-ebola-outbreak-by-his-excellencythe-president-dr-ernest-bai-koroma-july-30-2014 [hereinafter Address to the Nation]; Ernest Bai Koroma, President of Sierra Leone, Broadcast to the Nation on Further Measures to End the Ebola Outbreak by His Excellency the President Dr. Ernest Bai Koroma (Sept. 24, 2014), available at http://www.statehouse.gov.sl/index.php/usefullinks/1000-broadcast-to-the-nation-on-further-measures-to-end-the-ebola-outbreakby-his-excellency-the-president-dr-ernest-bai-koroma-september-24-2014.

60. Ellen Johnson Sirleaf, President of Liber., Statement Delivered by H. E. Ellen Johnson Sirleaf President of Liberia on the Lifting of the State of Emergency (Nov. 13, 2014), available at http://www.emansion.gov.lr/doc/State\%20of\%20Emergency $\% 20$ Speech \%20(Presedits).pdf (on November 13, 2014, President Sirleaf opted not to extend the emergency declaration in Liberia, citing progress made and public health powers available to continue the fight against Ebola).

61. See Constitution of Guinea 7 May 2010, title 5, art. 90, available at http:// unpan1.un.org/intradoc/groups/public/documents/unpan/unpan049269.pdf (the constitutional limit to the duration of an emergency declaration in Guinea is twelve days, unless extended by the National Assembly). However, in declaring an emergency, President Alpha Condé formally banned persons "from leaving their homes until the end of their surveillance period" and instituted a ban on moving bodies "from one town to another until the end of the epidemic." Guinea Declares a National Health Emergency, JAMAICA OBSERVER (Aug. 13, 2014, 7:39 PM), http:// www.jamaicaobserver.com/news/Guinea-declares-Ebola-a--national-healthemergency.

62. Constitution of Sierra Leone 1991, Act. No. 6, § 29(5), available at http:// www.sierra-leone.org/Laws/constitution1991.pdf. 
Guinea and Liberia similarly grant leaders leeway to coordinate and implement emergency response plans and to designate officials or entities in charge.

Most of these countries' constitutions also permit restricting certain public rights during emergencies. Explicit restraints on freedoms of assembly and association are constitutionally authorized in Nigeria and Sierra Leone, ${ }^{63}$ paving the way for significant enforcement of social distancing measures. The constitutions of Liberia, Nigeria, and Sierra Leone allow use of forced or compulsory labor during emergency periods, ${ }^{64}$ which could potentially authorize forced deployment of security forces ${ }^{65}$ and HCWs. ${ }^{66}$ Individual and group detentions are also permitted despite explicit infringements of personal rights to travel and assemble. Constitutional provisions in Nigeria, Sierra Leone, and Liberia authorize warranted border restrictions, regardless of an emergency declaration, ${ }^{67}$ despite WHO's rejection of such practices due to inhibitions on trade of essential medical goods. ${ }^{6}$ Only

63. See Constitution of Nigeria 1999, $\S$ 45(1)(a), available at http://www.wipo. int/wipolex/en/text.jsp?file_id=179202; Constitution OF SIERra Leone, Act. No. 6, $\S 26(2)(a)(i) 1991$, available at http://www.sierra-leone.org/Laws/constitution1991.pdf.

64. See Constitution of Nigeria 1999, §43(2)(d), available at http:// www.wipo.int/wipolex/en/text.jsp?file_id=179202; Constitution of Sierra Leone 1991, Act. No. 6, § 19(2)(d), available at http://www.sierra-leone.org/Laws/constitution1991.pdf; Constitution of THE Republic OF LiBeria 1986, § 12, available at http://www.liberianlegal.com/constitution1986.htm.

65. Liberia and Sierra Leone have deployed security forces to enforce Ebola containment measures, yet it is unclear if their deployment was "forced." Anne Look, Liberia, Sierra Leone Deploy Troops to Contain Ebola, Voice of Aм. (Aug. 8, 2014), http://www.voanews.com/content/liberia-sierra-leone-deploy-troops-to-contain-ebola/ 2407268.html.

66. Ebola Situation in Liberia: Non-Conventional Interventions Needed, WorLD Health OrG. (Sept. 8, 2014), http://www.who.int/mediacentre/news/ebola/8-septem ber-2014/en/.

67. Nigeria's constitution authorizes suspending freedom of movement rights when "reasonably justifiable . . . in the interest of defense, public safety, public order, public morality or public health." CONSTITUTION OF NigERIA 1999, § 45, available at http://www.wipo.int/wipolex/en/text.jsp?file_id=179202. Liberian constitutional powers provide exemption to one's freedom of movement, as long as the restriction protects the public's health. Constitution of the Republic OF Liberia 1986, art. 13, available at http://www.liberianlegal.com/constitution1986.htm. Sierra Leone's Constitution allows exclusion of non-citizens in addition to restricting movement within defined localities, as deemed necessary by the President. Constitution of Sierra LEONE 1991, Act. No. 6, § 29(6)(a), available at http://www.sierra-leone.org/Laws/ constitution1991.pdf.

68. Ebola and Marburg Virus Disease Epidemics: Preparedness, Alert, Control, and Evaluation, World Health Org. 32 (Aug., 2014), http://apps.who.int/iris/bit stream/10665/130160/1/WHO_HSE_PED_CED_2014.05_eng.pdf?ua=1\&ua=1 [hereinafter World Health ORG, Ebola and Marburg]. WHO asserts that such coercive measures would increase economic hardship and uncontrolled migration of people from affected countries, resulting in a higher risk of international Ebola transmission. Statement on the 3th Meeting of the IHR Emergency Committee Regarding the 2014 Ebola Outbreak in West Africa, World Health Org. (Oct. 23, 2014), http:// www.who.int/mediacentre/news/statements/2014/ebola-3rd-ihr-meeting/en/. 
Guinea's constitution notes that emergency circumstances do not justify suspension of human rights. ${ }^{69}$

On August 19, 2014, Liberia implemented a twenty-one-day quarantine of over 50,000 people in a Monrovian slum ${ }^{70}$ following an attack on an Ebola clinic. Facing public resistance and scrutiny, efforts to cordon the area were largely ineffective and lifted after just ten days. ${ }^{71}$ In Sierra Leone, the President ordered a three-day national lockdown instructing citizens to remain indoors from September 19-21. ${ }^{72}$ During this time, outreach workers canvassed residences educating the public on Ebola, handing out soap, identifying active cases, and removing bodies of EVD victims. ${ }^{73}$ Countries like Senegal, ${ }^{74}$ Nigeria ${ }^{75}$ Spain, France, Mali, and the United States ${ }^{76}$ have also isolated infected persons in health care settings to limit the numbers of Ebola cases in their jurisdictions. ${ }^{77}$

Restrictive measures like these, often enforced by the country's military or police forces, may be legally prescribed to contain infectious conditions or stymie acts of public resistance, fear, and denial. ${ }^{78}$ Concerning a condition like Ebola that can kill over half its victims in relatively short order, social distancing and other measures may arguably help control its spread. When such powers are abused, how-

69. See Constitution of Guinea May 7, 2010, title 2, art. 6 (2010), available at http:/unpan1.un.org/intradoc/groups/public/documents/unpan/unpan049269.pdf.

70. Norimitsu Onishi, Clashes Erupt as Liberia Sets an Ebola Quarantine, N.Y. Times, Aug. 21, 2014, at A1, available at http://www.nytimes.com/2014/08/21/world/ africa/ebola-outbreak-liberia-quarantine.html?_r=0.

71. Clair MacDougall, Liberian Government's Blunders Pile Up in the Grip of Ebola, TIME (Sept. 2, 2014), http://time.com/3247089/liberia-west-point-quarantinemonrovia/.

72. Adam Nossiter, Sierra Leone to Institute Three-Day Ebola Quarantine, N.Y. Times (Sept. 7, 2014), at A12, available at http://www.nytimes.com/2014/09/07/world/ africa/sierra-leone-to-impose-widespread-ebola-quarantine.html.

73. Chelsea J. Carter \& Umaru Fofana, Sierra Leone Plans Nationwide Lockdown to Stop Spread of Ebola, CNN (Sept. 8, 2014), http://www.cnn.com/2014/09/06/world/ africa/sierra-leone-ebola-lockdown/.

74. The Outbreak of Ebola Virus Disease in Senegal is Over, World Health ORG. (Oct. 17, 2014), http://www.who.int/mediacentre/news/ebola/17-october-2014/ en/.

75. Faisal Shuaib et al., Ebola Virus Disease Outbreak-Nigeria, July-September 2014, 63 Morbidity \& Mortality Wkly. Rep. 867, Oct. 3, 2014, http:// www.cdc.gov/mmwr/preview/mmwrhtml/mm6339a5.htm?s_cid=mm6339a5_w; Nigeria Free of Ebola, supra note 53.

76. Neil Versel, Alleged Lapse in Protocols With Ebola Patient Should Surprise Nobody, Forbes (Oct. 15, 2014, 12:36 PM), http://www.forbes.com/sites/neilversel/ 2014/10/15/alleged-lapse-in-protocols-with-ebola-patient-happens-should-surprise-no body/.

77. Farai Gundan, Official: The World Health Organization Declares Senegal and Nigeria Free from Ebola, Forbes (Oct. 23, 2014, 2:16 PM), http://www.forbes.com/ sites/faraigundan/2014/10/23/official-the-world-health-organization-declares-senegaland-nigeria-free-from-ebola/.

78. MacDougall, supra note 71. 
ever, they can unjustifiably infringe on human rights and freedoms to the detriment of the public's health.

\section{Emergency Responses and Human Rights}

Overzealous and unfounded disease control measures can impinge basic human rights leading ultimately to the spread of disease detrimental to the public's health. Human rights are universal principles ${ }^{79}$ that include positive rights to life, liberty, security, travel, health, food, housing, and education, as well as freedoms of movement, of religious belief, and from discrimination. ${ }^{80}$ Health and human rights pioneer Jonathan Mann observed during the HIV/AIDS epidemic that threatening and excluding infected persons tend to drive cases of HIV underground, thwarting education and prevention efforts. ${ }^{81}$ Mann's research illustrates how protecting and promoting health and human rights are linked. ${ }^{82}$ The United Nation's High Commissioner for Human Rights, Zeid Ra'ad Al Hussein, echoed Mann's wisdom in emphasizing how respect for human rights can prevent and cure disease, while ill-advised measures can drive cases underground. ${ }^{83}$

Still, thirty years later, restrictive public health measures that may infringe upon human rights are being implemented in response to Ebola. ${ }^{84}$ As noted in Part II, a lack of functioning health care facilities in Ebola-affected countries denies individuals access to basic health care services ${ }^{85}$ in contravention of their human right to health. Developed countries also have a duty to provide international assistance to developing nations to realize fulfillment of their human rights obligations.

79. Nearly all countries have ratified the International Covenant on Economic, Social, and Cultural Rights ("ICESCR") and the International Covenant on Civil and Political Rights ("ICCPR"), including Guinea, Sierra Leone, and Liberia. LAWRENCE O. Gostin, Global Health L. 243-44 (2014).

80. International Federation of Red Cross and Red Crescent Societies \& FrancoisXavier Bagnoud Center for Health and Human Rights, Human Rights: An Introduction, in Health and Human Rights: A Reader 21 (Jonathan Mann et al. eds., 1999); Universal Declaration of Human Rights, G.A. Res. 217 (III) A, U.N. Doc. A/ RES/217(III) (Dec. 10, 1948).

81. Health and Human Rights: A Reader 5 (Jonathan Mann et al. eds., 1999); Patrick M. Eba, Commentary, Ebola and Human Rights in West Africa, 384 LANCET 2091 (2014), available at http://ac.els-cdn.com/S0140673614614124/1-s2.0S0140673614614124-main.pdf?_tid=1b30a140-b262-11e4-981a-00000aab0f01\&acdnat= 1423709696_9a3898f74ddfba393c2a7b301ac3fa44.

82. Gostin, supra note 79, at 244; see generally Elizabeth Fee \& Manon Parry, Jonathan Mann, HIV/AIDS, and Human Rights, 29 J. Pub. Health Pol. 54 (2008).

83. Press Conference by Zeid Ra'ad Al Hussein, U.N. High Commissioner for Human Rights (Oct. 16, 2014), available at http://www.ohchr.org/EN/NewsEvents/ Pages/DisplayNews.aspx?NewsID $=15173 \&$ LangID $=\mathrm{E}$.

84. Jonathan Mann et al., Health and Human Rights, in Health and Human

Rights: A ReAder 7, 13 (Jonathan Mann et al. eds., 1999).

85. Onishi, supra note 70. 
Yet, human rights are not absolute. In times of crisis, they may be restricted. The Siracusa Principles ${ }^{86}$ identify circumstances in which public health measures, like quarantine, may restrict human rights. Restrictions must: (1) be provided for and carried out in accordance with the law; (2) advance a legitimate objective of general interest; (3) be strictly necessary in a democratic society to achieve the objective; (4) represent the least intrusive means available to achieve the objective; (5) be based on scientific evidence and not drafted or imposed arbitrarily ${ }^{87}$ (6) be subject to review ${ }^{88}$ and (7) be limited in duration. ${ }^{89}$ Public health control measures that comply with the Siracusa Principles may justifiably infringe on human rights.

In other cases, infringements may be unacceptable, ${ }^{90}$ including through overzealous applications of social distancing measures in response to Ebola. Doctors Without Borders suggested Sierra Leone's three-day lockdown, for example, led individuals to hide their symptoms and deceased family members and deprived the poor of access to increasingly expensive food. ${ }^{91}$ On August 7, 2014, Sierra Leone's army reportedly blockaded Ebola-affected areas, limiting persons' rights to travel (whether infected or not) and impeding their ability to obtain necessities. ${ }^{92}$ Human Rights Watch alleged Liberia's ten-day quarantine $\mathrm{g}^{93}$ of thousands of residents in West Point, Monrovia, significantly and disproportionally affected the poor, elderly, and others unable to evade restriction, ${ }^{94}$ in contravention of multiple Siracusa Principles. ${ }^{95}$ Closures of borders and markets, movement restrictions,

86. United Nations, Econ. \& Soc. Council, Siracusa Principles on the Limitation and Derogation Provisions in the International Covenant on Civil and Political Rights, U.N. Doc. E/CN.4/1985/4, Annex (1985), available at http://www1.umn.edu/humanrts/ instree/siracusaprinciples.html [hereinafter Siracusa Principles].

87. Id. at Annex IA; WHO Guidance on Human Rights and Involuntary Detention for xdr-tb Control, World Health ORg. (Jan. 24, 2007), http://www.who.int/tb/ features_archive/involuntary_treatment/en/.

88. Siracusa Principles, supra note 86, at Annex IIC.

89. Id.

90. Gostin, supra note 79, at 244.

91. Lizzie Dearden, Ebola Virus Outbreak: 92 Bodies Recovered as More Cases Found in Sierra Leone Lockdown, InDEPENDENT (Sept. 22, 2014), http:// www.independent.co.uk/news/world/africa/ebola-outbreak-92-bodies-recovered-asmore-cases-found-in-sierra-leone-lockdown-9748181.html.

92. Umaru Fofana \& Clair MacDougall, Sierra Leone Army Blockades Ebola Areas, Liberia Declares Emergency, Reuters (Aug. 7, 2014, 7:20 PM), http://www. reuters.com/article/2014/08/07/us-health-ebola-africa-idUSKBN0G70WW20140807.

93. Kevin Hartnett, With Ebola, Mass Quarantine is Back, Bos. Globe (Oct. 3, 2014), http://www.bostonglobe.com/ideas/2014/10/03/with-ebola-mass-quarantineback/dpLJ0IYYTwdHk1AFUY1QGP/story.html; External Situation Report, U.N. Mission fOR EBOLA EMERGENCY Response (Oct. 9, 2014), http://ebolaresponse.un. org/sites/default/files/situation_report-ebola-09oct14.pdf.

94. West Africa: Respect Rights in Ebola Response, Hum. Rтs. Waтch (Sept. 15, 2014), http://www.hrw.org/news/2014/09/15/west-africa-respect-rights-ebola-response.

95. Fiona Lander, Human Rights and Ebola: The Issue of Quarantine, PLoS BLOGS (Nov. 5, 2014), http://blogs.plos.org/globalhealth/2014/11/ebola_and_human _rights/. 
and a lack of able workers caused food prices to escalate in Sierra Leone and Liberia. ${ }^{96}$ Liberian officers reportedly seized belongings of those violating curfew and extorted individuals at checkpoints. ${ }^{97}$ When the border between Liberia and Sierra Leone was closed in mid-August, Liberian armed forces were ordered to shoot on-sight anyone unlawfully entering the country. ${ }^{98}$ In late October, forty-three people quarantined in Jenewonda, Liberia, threatened to break out because they had no food. ${ }^{99}$ These and other reports implicate serious violations of human rights to life, health, security, freedom, and food outside the bounds of Siracusa Principles.

HCWs attempting to provide medical care and public health services have been harassed and attacked due to a lack of EVD education and mistrust. Eight HCWs were brutally murdered in Guinea while educating the public on how to prevent the spread of Ebola. ${ }^{100}$ Survivors, family members of those infected with Ebola, and orphans have been ostracized and discriminated against, leaving them without adequate food, housing, and care. ${ }^{101}$

WHO warned against national travel bans and restrictions, arguing they will lead to human rights violations and worsened health outcomes by undermining response efforts. ${ }^{102}$ Still multiple countries have imposed bans. Saudi Arabia denied visas to 7,000 West African Muslims registered for the Hajj. ${ }^{103}$ Developed countries have restricted flights and other travel to and from the affected regions. In late October, Australia announced that it will not process any visas from Ebola-affected countries; those who already have visas may only enter the country after serving a twenty-one-day quarantine prior to

96. Nebehay \& Giahyue, supra note 41.

97. UNMEER, supra note 93.

98. APA, Liberia: Border Guards Given Shoot-on-Site Orders, STAR AfricA (Aug. 18, 2014, 3:42 PM), http://en.starafrica.com/news/liberia-border-guards-givenshoot-on-sight-orders.html.

99. External Situation Report, UNMEER (Oct. 24, 2014), http://ebolaresponse .un.org/sites/default/files/situation_report-ebola-24oct14.pdf; Jonathan Paye-Layleh \& Clarence Roy-Macaulay, Threat to Break Isolation in Liberia Over Food, AssocIATED Press (Oct. 23, 2014, 10:06), http://www.usnews.com/news/world/articles/2014/ 10/23/threat-to-break-isolation-in-liberia-over-food.

100. Ebola Outbreak: Guinea Health Team Killed, BBC News Afr. (Sept. 19, 2014), http://www.bbc.com/news/world-africa-29256443.

101. Michelle Nichols \& James Harding Giahyue, Defying Stigma, Survivors Join the Ebola Fight in West Africa, Reuters Afr. (Oct. 27, 2014, 6:46 PM), http:// af.reuters.com/article/nigeriaNews/idAFL5N0SM2GE20141027?feedTypeRSS\&feed Name $=$ NigeriaNews $\& s p=$ true.

102. Caelainn Hogan, WHO Wary of Ebola Travel Bans, WAsh. Post, Aug. 19, 2014, at A02, available at http://www.washingtonpost.com/national/health-science/ 2014/08/19/83da2974-26f2-11e4-8593-da634b334390_story.html.

103. UN Ebola Crisis Centre: External Situation Report, UNMEER (Oct. 2, 2014), http://ebolaresponse.un.org/sites/default/files/situation_report-ebola-02oct14.pdf. 
their departure. ${ }^{104}$ Days later, Canada followed with similar restrictions. ${ }^{105}$ Singapore announced that citizens of Liberia, Guinea, and Sierra Leone need a visa to enter effective November 5, 2014. ${ }^{106}$

Awareness of these and other human rights implications has led the UN, UNICEF, and others to limit negative impacts. The UN is training armed forces in Freetown, Sierra Leone to institute proper procedures at checkpoints, screening areas, and quarantines that respect human rights, including assuring adequate access to food and water for affected persons. ${ }^{107}$ UNICEF and Liberian partners opened a dedicated children's care center for those who have lost a parent or parents to Ebola and must undergo quarantine. ${ }^{108}$ UNICEF plans to train 2,500 Ebola survivors (assumed to be immune to the disease) to care for quarantined and orphaned children and to assist in reuniting families. ${ }^{109}$ Despite a slow and criticized international response, over half of WHO's \$988 million plan has been funded and another \$279 million pledged. ${ }^{110}$ The UN Coordination of Humanitarian Affairs Office estimates countries have committed $\$ 894$ million and pledged another $\$ 928$ million for preparedness needs. ${ }^{111}$ International pledges of HCWs, other personnel, and resources continue to rise. ${ }^{112}$

\section{Empirical Foundations of Public Health Legal MeAsures}

In the throes of a highly infectious and deadly disease within resource-poor West African countries facing thousands of current and future cases and major collateral harms, a plethora of public health measures to counter Ebola may seem viable. However, three critical questions underlying the justified use of any restrictive public health

104. Euan McKirdy, Australia Instigates Ebola-Prompted Ban on Travel from West Africa, CNN, http://www.cnn.com/2014/10/28/world/asia/australia-immigration-policyebola/ (last updated Oct. 28, 2014, 3:57 PM).

105. Ebola Crisis: Canada Visa Ban Hits West Africa States, BBC News U.S. \& CAN. (Nov. 1, 2012), http://www.bbc.com/news/world-us-canada-29861563.

106. Claire Huang, Nationals from Ebola-Hit West African Countries Need Visa to Enter Singapore from Nov 5, Bus. Times (Nov. 3, 2014), http://www.businesstimes .com.sg/government-economy/nationals-from-ebola-hit-west-african-countries-needvisa-to-enter-singapore-from.

107. External Situation Report, UNMEER (Oct. 14, 2014), http://ebolaresponse .un.org/sites/default/files/situation_report-ebola-14oct14.pdf.

108. Id.

109. $I d$.

110. Tiaji Salaam-Blyther, Congressional Research Serv., RL43697, U.S. and International Health Responses to the Ebola Outbreak in West AfRICA, 12-13 (2014), available at http://fas.org/sgp/crs/row/R43697.pdf.

111. $I d$. at 13 .

112. The U.S. currently has 900 governmental employees in West Africa, Britain sent 750 troops, including some medical officers, China pledged 170 health workers, Cuba pledged $165 \mathrm{HCWs}$, and the East African Community has deployed 600 workers; in addition, many other nations are providing financial and medical resources to fight Ebola outbreaks. Id. at 14-15. 
intervention must be asked. First, is the intervention authorized by routine or emergency public health laws in the affected jurisdiction? ${ }^{113}$ Second, does implementation of the intervention negatively impact the human rights of individuals without public health justification? ${ }^{114}$ If so, the measure may fail to promote global health based on existing theory and research.

Finally, is the public health measure efficacious? Public health measures that are lawful and consistent with human rights norms may still fail to effectively control diseases. Conversely, measures of questionable legality that infringe upon human rights may prove efficacious. These issues are addressed below through three case studies-focused on the efficacy of isolation, border closure, and lockdown-and related observations about the essential facets of efficacy of public health legal measures to control emerging infectious diseases.

\section{A. Case Study 1 - Isolation}

Isolation of patients with highly infectious diseases, ${ }^{115}$ including EVD, ${ }^{116}$ is routinely used to prevent the spread of the illness to patients, HCWs, family members, or others. Research suggests the practice curtails disease transmission, especially concerning conditions like Ebola that are not as easily transmitted as airborne viruses like influenza or measles. ${ }^{117}$ Proper use of barrier-nursing techniques and isolation of infected patients has historically been effective in reducing transmission to HCWs and limiting the spread of EVD in the greater community. ${ }^{118}$

113. See supra Part III.

114. See supra Part IV.

115. Isolation is "the separation, for the period of communicability, of known infected persons in such places and under such conditions as to prevent or limit the transmission of the infectious agent." Lawrence O. Gostin \& Benjamin E. Berkman, Pandemic Influenza: Ethics, Law, and the Public's Health, 59 Admin. L. Rev. 121, 171 (2007).

116. CDC guidance from October 2014, as updated on February 12, 2015, recommends isolation for confirmed and suspected cases of EVD. Identify, Isolate, Inform: Emergency Department Evaluation and Management for Patients Who Present with Possible Ebola Virus Disease, U.S. Ctrs. for Disease Control \& Prevention (Feb. 12, 2015), http://www.cdc.gov/vhf/ebola/hcp/ed-management-patients-possibleebola.html.

117. See generally Christophe Fraser et al., Factors That Make an Infectious Disease Outbreak Controllable, 101 Proc. NAT'L ACAD. SCI. U.S. 6146 (2004) (isolation effective against SARS and other illnesses with post-symptomatic infectivity and moderate transmissibility, but not effective against influenza, using mathematical models).

118. For example, in the 1995 EVD outbreak in Kikwit, 67 HCWs became infected and 47 died prior to the implementation of proper patient isolation and the use of protective gear; only 3 infections occurred after implementation. Barbara Kerstiëns \& Francine Matthys, Interventions to Control Virus Transmission During an Outbreak of Ebola Hemorrhagic Fever: Experience from Kikwit, Democratic Republic of the Congo, 1995, 179 (Supp. 1) J. Infectious Diseases S263, S267 (1999) ("Key elements in the control of an [EVD] outbreak are the organization of an adequate isolation unit for suspected cases and the use of proper barrier-nursing techniques, using 
Isolation nevertheless has some significant potential drawbacks. Its practice requires significant resources ${ }^{119}$ and impacts individuals' personal liberties. ${ }^{120}$ Isolated patients experience negative mental health effects, including depression, anxiety, and anger, and report dissatisfaction with their treatment. ${ }^{121}$ Dr. Kent Brantly, one of the first Western doctors to survive Ebola, described his isolation as a lonely experience: "I needed help to go to the bathroom, I needed water to drink. . . I I was scared and there was nobody there." 122 HCWs may spend less time with isolated patients who thus experience more adverse events and failures of supportive care. ${ }^{123}$

Significant debates among researchers and mathematical modelers challenge a presumption of efficacy of isolation in all cases. While evidence from past EVD outbreaks supports the efficacy of isolation, empirical evidence that isolation reduces disease transmission is lacking for some illnesses, including methicillin-resistant Staphylococcus aureus ("MRSA"), influenza, and HIV. ${ }^{124}$ Theoretical modeling testing isolation's efficacy has indicated that isolation should be more effective against EVD than several other illnesses. For example, mathematical models of the 2003 severe acute respiratory syndrome

protective equipment in adequate quantities"). See also C.J. Peters \& J.W. LeDuc, An Introduction to Ebola: The Virus and the Disease, 179 (Supp. 1) J. Infectious Diseases ix (1999) (reviewing multiple past outbreaks); G. Chowell et al., The Basic Reproductive Number of Ebola and the Effects of Public Health Measures: The Cases of Congo and Uganda, 229 J. Theoretical Biology 119, 121 (2004) (isolation and protective equipment helped halt the 1995 and 2000 outbreaks); M. Lamunu et al., Containing a Haemorrhagic Fever Epidemic: The Ebola Experience in Uganda (October 2000-January 2001), 8 INT'L J. INFECTIOUs DisEASEs 27, 28 (2004) (isolation and other control interventions were "very successful in containing the epidemic" in Uganda in 2000-2001); R.T. Emond et al., A Case of Ebola Virus Infection, 2 BRIT. MED. J. 541 (1977) (isolation of the single patient and barrier-nursing techniques prevented any further infections).

119. Kathryn B. Kirkland, Taking off the Gloves: Toward a Less Dogmatic Approach to the Use of Contact Isolation, 48 CLINICAL Infectious Diseases 766, 766 (2009) ("[I]solation has costs, including the opportunity costs associated with the use of health care resources.").

120. Gostin \& Berkman, supra note 115 , at 172.

121. C. Abad et al., Adverse Effects of Isolation in Hospitalized Patients: A Systematic Review, 76 J. Hospital Infection 97 (2010); Mark Cole \& Louise Lai, Reviewing the Efficacy of Infection Control Isolation, 18 BRIT. J. NuRsing 403 (2009); Kirkland, supra note 119, at 766. These three reviews focused mainly on studies of patients with infections like MRSA for which only contact isolation is used, though a few of the studies concerned patients experiencing more severe forms of isolation for illnesses such as SARS.

122. Betsy McKay, In Depth: Ebola Patients Tread Painful, Lonely Journeys to Recovery, Wall ST. J. (Asia), Nov. 3, 2014, at 16, available at http://online.wsj.com/ articles/u-s-ebola-survivors-tread-painful-lonely-journeys-1414801784.

123. Abad et al., supra note 121, at 99, 101; Kirkland, supra note 119, at 768.

124. Kirkland, supra note 119, at 767 (evidence lacking on contact isolation's efficacy against MRSA infections); Cole \& Lai, supra note 121, at 404 (evidence lacking on contact isolation's efficacy against MRSA infections); Fraser et al., supra note 117, at 6151 (arguing that isolation, contact tracing, and quarantine are unlikely to be successful against an influenza or HIV outbreak via mathematical models). 
("SARS") outbreak indicated its control was made possible solely through isolation. ${ }^{125}$ Modeling data based on the 2014 EVD outbreak in Liberia, however, suggests that isolation alone is insufficient to contain the disease. ${ }^{126}$ Only in combination with other control measures, such as sanitary burial, contact tracing, and quarantine, may it limit the spread of Ebola. ${ }^{127}$

Patient isolation can be effective, but it is not failsafe due to key practical difficulties. Delays in implementing isolation and other control measures reduce their effectiveness. ${ }^{128}$ Even with proper equipment and training, compliance with isolation procedures is rarely $100 \% .{ }^{129}$ Studies suggest HCW compliance rates fall below $30 \%$ for illnesses requiring only contact isolation, such as MRSA. ${ }^{130}$ Even after isolation, Ebola patients and corpses can transmit EVD. The isolation of Thomas Eric Duncan still resulted in at least two HCWs contracting Ebola. ${ }^{131}$ In Spain, a HCW was infected while providing treatment ${ }^{132}$ amidst reported lapses in the hospital's existing isolation and treatment protocols. ${ }^{133}$ Still, with sufficient resources and sound execution, patient isolation can slow the spread of EVD, as shown in past outbreaks, and remains a key component of any intervention strategy against Ebola.

125. Fraser et al., supra note 117, at 6151 (finding that isolation alone could contain an outbreak of an illness like SARS, with only post-symptomatic infectivity and moderate transmissibility); Abba B. Gumel et al., Modelling Strategies for Controlling SARS Outbreaks, 271 Proc. Royal Soc'y London B 2223, 2223 (2004); James O. Lloyd-Smith, Alison P. Galvani \& Wayne M. Getz, Curtailing Transmission of Severe Acute Respiratory Syndrome Within a Community and its Hospital, 270 Proc. Royal Soc'y London B 1979, 1979 (2003).

126. Abhishek Pandey et al., Strategies for Containing Ebola in West Africa, 346 SCIENCE 991, 991 (2014), available at http://www.sciencemag.org/content/early/2014/ 10/29/science.1260612.full.

127. Id. at 993-94; Chowell et al., supra note 118, at 124-25 (aggregated control measures include surveillance, quarantine, education on strict barrier nursing techniques [including isolation] and the rapid burial or cremation of deceased patients).

128. Fraser et al., supra note 117, at 6150; J. Legrand et al., Understanding the Dynamics of Ebola Epidemics, 135 EPIDEMIOLOGY INFECTION 610, 610 (2006) (mathematical model of an EVD epidemic demonstrating the importance of rapid institution of control measures); Chowell et al., supra note 118, at 119 (mathematical model showing a two-week delay in implementing control measures doubles the final EVD epidemic size).

129. Even $90 \%$ isolation would be difficult if not impossible to achieve in West Africa. Pandey et al., supra note 126, at 994.

130. Cole \& Lai, supra note 121, at 406 (noting that HCW compliance in another study increased to $97 \%$ when dealing with feces, lending to potential increased compliance with a known deadly pathogen such as EVD).

131. Versel, supra note 76.

132. Ebola Response Roadmap Situation Report, World Health Org. 1, 9 (2014), http://apps.who.int/iris/bitstream/10665/137376/1/roadmapsitrep_29Oct 2014_eng.pdf.

133. Ilan Brat et al., Workers at Madrid Hospital Say Spain Was Ill-Prepared for Ebola, WALl ST. J. (Oct. 15, 2014, 7:05 AM), http://online.wsj.com/articles/workersat-madrid-hospital-say-spain-was-ill-prepared-for-ebola-1413320546?KEYWORDS= Spain \%20ebola. 


\section{B. Case Study 2 - Border Closures}

Border closures entail multiple types of prohibitions on individuals' entry into or exit from countries or regions via land, air, or water. ${ }^{134}$ They have been used in prior large-scale outbreaks, such as the SARS epidemic. ${ }^{135}$ However, WHO has consistently recommended against border closures in response to Ebola. ${ }^{136}$ The International Federation of Red Cross and Red Crescent Societies described border closures as "very irrational."137 Nevertheless, these powers have been used extensively in countries impacted by Ebola, as well as those seeking to prevent its importation.

On June 11, 2014, Sierra Leone closed its borders with Guinea and Liberia to bolster Ebola containment efforts after confirming sixteen cases. $^{138}$ On July 27 , Liberia closed all but three of its border entry points in an effort to screen all travelers for Ebola. ${ }^{139}$ Liberia and Sierra Leone closed borders well before issuing formal emergency declarations. ${ }^{140}$ Guinea officially shut its borders on August 9, just

134. Security Message for U.S. Citizens: Dakar (Senegal), Border Closures Due to Ebola Virus Disease, Overseas Sec. Advisory Council (Aug. 25, 2014), https:// www.osac.gov/pages/ContentReportDetails.aspx?cid=16206.

135. See CDC Telebriefing on Ebola Outbreak in West Africa, U.S. CTrs, FOR DisEASE ConTrol (July 28, 2014, 2:30 PM), http://www.cdc.gov/media/releases/2014/ t0728-ebola.html; Drew Hinshaw \& Betsy Mckay, West Africa Strains to Contain Ebola Virus, Wall ST. J. (July 29, 2014, 2:45 PM), http://online.wsj.com/articles/liberia-shuts-borders-amid-ebola-outbreak-1406568519; Influenza Pandemic in Australia 1918-19, Melbourne Statistics, Australian Postal Hist. \& Stat., http://www.aus postalhistory.com/articles/1123.php (last visited Oct. 31, 2014); Sue Chan, China Blocks Borders Over SARS, CBS News (May 2, 2003, 4:49 PM), http:// www.cbsnews.com/news/china-blocks-borders-over-sars; Kate Saunders, Tibet Border with Nepal Closed to Prevent Spread of SARS, Phayul.com (Apr. 27, 2003, 10:30 AM), http://www.phayul.com/news/article.aspx?id=4104\&t=1; Michael Wines, The SARS Epidemic: Moscow; Russia Urges Travel Limit on Suspicion of SARS Case, N.Y. Times, May 9, 2003, at A13, available at http://www.nytimes.com/2003/05/09/ world/the-sars-epidemic-moscow-russia-urges-travel-limit-on-suspicion-of-sars-case .html.

136. Travel and transport risk assessment: Interim guidance for public health authorities and the transport sector, WORLD HEALTH ORG. 6-7, http://apps.who.int/iris/bit stream/10665/132168/1/WHO_EVD_Guidance_TravelTransportRisk_14.1_eng.pdf?ua $=1 \& u a=1$ (last visited Feb. 12, 2014).

137. Michael Martina, Red Cross Head Says Ebola Travel Bans 'Irrational,' REuTERS (Oct. 22, 2014, 5:33 AM), http://www.reuters.com/article/2014/10/22/ushealth-ebola-redcross-idUSKCN0IB0WF20141022.

138. Umaru Fofana, Sierra Leone Shuts Borders, Closes Schools to Fight Ebola, REUTERS (June 11, 2014, 8:55 PM), http://uk.reuters.com/article/2014/06/11/us-healthebola-leone-idUKKBN0EM2CG20140611.

139. Ellen Johnson Sirleaf, President of Liber., A Special Statement by the President (July 27, 2014), available at http://www.emansion.gov.lr/doc/Special\%20Statement \%20by\%20President\%20Ellen\%20Johnson\%20Sirleaf\%20-1_1.pdf.

140. Formal states of emergency were not declared until July 30, 2014, in Sierra Leone and August 6, 2014, in Liberia. See Address to Nation, supra note 59; Ellen Johnson Sirleaf, President of Liber., Statement on the Declaration of Emergency by President Ellen Johnson Sirleaf, R.L. (Aug. 6, 2014), available at http:// www.emansion.gov.lr/doc/sdseg.pdf. 
days after WHO declared a PHEIC. ${ }^{141}$ Senegal closed its land borders with Guinea and air borders with Nigeria, Sierra Leone, and Liberia. ${ }^{142}$ Cote d'Ivorie shut off its borders with Nigeria, Liberia, and Sierra Leone. ${ }^{143}$ In late October, several countries stopped issuing visas to persons from the regions most affected by the virus. ${ }^{144}$

Border closures can potentially derail the flow of Ebola into a country, but also can limit importation of HCWs,${ }^{145}$ food, and medical supplies to needed areas, ${ }^{146}$ effectively cutting off impacted regions. ${ }^{147}$ Without sufficient enforcement, border closures may be futile. ${ }^{148}$ Measuring their effectiveness is difficult in part because they are generally used in conjunction with other disease prevention measures. ${ }^{149}$ However, some studies have used mathematical simulation models to estimate the spread of influenza due to border restrictions. In 2006, researchers used a large-scale epidemic simulation to examine potential intervention options to address a novel influenza outbreak in Great Britain or the United States. ${ }^{150}$ Researchers found that border restrictions, even if $99.9 \%$ effective, may delay the peak of the U.S. pandemic by six weeks, but would not prevent the spread entirely. ${ }^{151}$ Another study examined the spread of flu following flight restrictions

141. Saliou Samb, Guinea Shuts Borders with Sierra Leone, Liberia in Bid to Halt Ebola, Reuters (Aug. 9, 2014, 11:09 PM), http://uk.reuters.com/article/2014/08/09/ukhealth-ebola-borders-idUKKBN0G90DN20140809.

142. Travel Restrictions, Flight Operations and Screening, INT'L SOS, https:// www.internationalsos.com/ebola/index.cfm?content_id=435\& (last updated Jan. 28, 2015).

143. Id.

144. Ralph Ellis, Canada to Stop Processing Visas from Ebola Hot Spots in West Africa, CNN (Oct. 31, 2014, 6:05 PM), http://www.cnn.com/2014/10/31/world/worldebola-outbreak.

145. Heidi Vogt, Travel Restrictions Hamper African Medical Staff in Ebola Fight, WALL ST. J. (Oct. 24, 2014), http://online.wsj.com/articles/travel-restrictions-hamperafrican-medical-staff-in-ebola-fight-1414086147. WHO recommends health authorities conduct an in-depth risk/benefit analysis before carrying out any such measure if implementing such controls is unavoidable. See World Health Org., Ebola and Marburg, supra note 68.

146. S.A. Miller, A Top Health Expert Warns Against Closing Borders to Stop Ebola, WAsH. Times, Oct. 6, 2014, http://www.washingtontimes.com/news/2014/oct/6/ a-top-health-expert-warns-against-closing-borders-/; Nossiter, supra note 40.

147. See Giugale, supra note 39.

148. Tom Odula \& Lynsey Chutel, Africa Stems Ebola Via Border Closings, Luck, Associated Press (Oct. 17, 2014, 7:15 AM), http://news.yahoo.com/africa-stemsebola-via-border-closings-luck-182548855.html; Charlotte Alter, Liberia Closes Borders to Curb Ebola Outbreak, TIME (July 28, 2014), http://time.com/3046012/liberiaborder-ebola/.

149. See, e.g., Timothy C. Germann et al., Mitigation Strategies for Pandemic Influenza in the United States, 103 Proc. Nat'l Acad. ScI. U.S. 5935, 5936 (2006); T. Déirdre Hollingsworth et al., Will Travel Restrictions Control the International Spread of Pandemic Influenza?, 12 NAture Med. 497, 498 (2006).

150. Neil M. Ferguson et al., Strategies for Mitigating an Influenza Pandemic, 442 NAture 448, 448-49 (2006).

151. Id. at 449 . 
due to the $9 / 11$ terrorist attacks. ${ }^{152}$ Researchers discovered that the peak date of 2001-2002 flu season in the United States was delayed by approximately one month, a delay not seen in France where flight restrictions were not imposed. ${ }^{153}$ Even if border closures and flight restrictions delay the spread of disease, they do not eliminate the risk entirely.

Varied border control policies in Nigeria and Senegal are illustrative. Both countries had limited numbers of Ebola cases initially, but within weeks were declared "Ebola free" by WHO. ${ }^{154}$ Senegal initially closed its borders with Guinea in March 2014, but re-opened land borders in May, ${ }^{155}$ only to close them again on August $21 .{ }^{156} \mathrm{Re}$ ports conflict as to whether a Guinean university student, who became Senegal's first and only confirmed case of EVD, entered the country before or after the August 21 border closure. ${ }^{157}$ Due to the discrepancy in the timeline of the Guinean university student's crossing into Senegal, Senegal's EVD case is interpreted by some as an example of the ineffectiveness of border closures, while others suggest border closures kept further disease out of the country. ${ }^{158}$ Conversely, Nigeria never closed its national borders while eradicating the disease. Despite their varying approaches to border closures, both countries moved quickly to trace contacts of the initial cases. ${ }^{159}$ Rigorous contact tracing and follow-up with potential cases are credited by WHO

152. John S. Brownstein et al., Empirical Evidence for the Effect of Airline Travel on Inter-Regional Influenza Spread in the United States, 3 PLoS Med. 1826, 1826 (2006).

153. Id. at $1829-30,1832$.

154. WHO Declares End of Ebola Outbreak in Nigeria, World Health Org. (Oct. 20, 2014), http://www.who.int/mediacentre/news/statements/2014/nigeria-endsebola/en/; WHO Congratulates Senegal on Ending Ebola Transmission, WorLD Health Org. (Oct. 17, 2014), http://www.who.int/mediacentre/news/statements/2014/ senegal-ends-ebola/en.

155. Ebola Crisis: Senegal Defends Guinea Border Closure, BBC News Afr. (Aug. 22, 2014, 5:36 PM), http://www.bbc.com/news/world-africa-28893835.

156. Ray Sanchez, Senegal Confirms First Ebola Case, CNN (Aug. 29, 2014, 5:38 PM), http://www.cnn.com/2014/08/29/health/ebola-outbreak-senegal/.

157. Babacar Dione, Ebola Arrives in Senegal as Outbreak Accelerates, WAsH. TIMEs (Aug. 29, 2014), http://www.washingtontimes.com/news/2014/aug/29/who-moreebola-cases-in-past-week-than-any-other/?page=all.

158. Ebola Spreads to Senegal After Student Evades Health Monitors, CBC News (Aug. 29, 2014, 10:48 PM), http://www.cbc.ca/news/world/ebola-spreads-to-senegal-after-student-evades-health-monitors-1.2750314; Student Slips Over Border, Spreads Ebola to Senegal, NBC News (Aug. 29, 2014, 1:28 PM), http://www.nbcnews.com/ storyline/ebola-virus-outbreak/student-slips-over-border-spreads-ebola-senegaln192216; Vigilante 'Border Guards' Keeping Ebola out of Senegal, Bus. Day Live (Sept. 7, 2014, 7:51 PM), http://www.bdlive.co.za/africa/africannews/2014/09/06/vigilante-border-guards-keeping-ebola-out-of-senegal.

159. Kelsey Mirkovic et al., Importation and Containment of Ebola Virus DiseaseSenegal, August-September 2014, 63 Morbidity \& Mortality Wrly. Rep. 873, U.S. CTrs. For Disease Control \& Prevention (Oct. 3, 2014), http://www.cdc.gov/ $\mathrm{mmwr} / \mathrm{preview} / \mathrm{mmwrhtml} / \mathrm{mm} 6339 \mathrm{a} 6 . \mathrm{htm}$ ?s_cid=mm6339a6_w; Nigeria Free of Ebola, supra note 53. 
as crucial steps to preventing further disease spread within these two countries. ${ }^{160}$

\section{Case Study 3 - Lockdown}

On September 6, 2014, Sierra Leone announced a three-day lockdown of all residents in place from September 19-22. ${ }^{161}$ The objective was clear. As people remained in residences and out of public spaces, government officials would canvass the country, assess the impacts of Ebola, identify new cases, and remove the bodies of victims. The lockdown ended with Sierra Leone's government declaring success $^{162}$ in locating new patients and removing bodies for safe burial. ${ }^{163}$ However, operational pitfalls and risks plagued its execution and led to collateral damages. Doctors Without Borders concluded: "[L]ockdowns ... do not help control Ebola as they end up driving people underground and jeopardising [sic] the trust between people and health providers." 164

Sierra Leone's lockdown appears to be unique as a public health measure. In reality it assimilated several traditional practices. Its breadth is similar to large-scale quarantine actions (also known as cordon sanitaire) used typically to cordon off persons who may have been exposed to infectious diseases for the duration of its incubation. During the SARS outbreak, Toronto quarantined 13,000 people who may have been exposed to the disease. ${ }^{165}$ The necessity of widespread quarantine of roughly 100 people for each actual SARS case identified have been criticized. ${ }^{166}$ Quarantine has been shown to effectively reduce the spread of smallpox in an attack scenario. ${ }^{167}$ Unlike tradi-

160. See Nigeria and Senegal: Stable-for the Moment, World Health Org., http://www.who.int/csr/disease/ebola/ebola-6-months/nigeria-senegal/en (last visited Nov. 18, 2014); Dennis Lynch, How to Stop an Ebola Outbreak: Lessons from Nigeria and Senegal, INT'L Bus. TIMEs (Oct. 16, 2014, 2:40 PM), http://www.ibtimes.com/howstop-ebola-outbreak-lessons-nigeria-senegal-1706297.

161. Bill Chapell, Ebola Spurs a Full Public Lockdown in Sierra Leone, WRVO Pub. Media (Sept. 6, 2014, 12:45 PM), http://wrvo.org/post/ebola-spurs-full-publiclockdown-sierra-leone.

162. Umaru Fofana, Sierra Leone Wraps up Three-Day Ebola Lockdown, ReUTERS (Sept. 21, 2014, 10:57 PM), http://uk.reuters.com/article/2014/09/21/us-health-ebolaleone-idUKKBN0HG0NW20140921.

163. Naina Bajekal, Ebola Lockdown in Sierra Leone Finds 150 New Cases, TIME (Sept. 22, 2014), http://time.com/3417907/ebola-sierra-leone-lockdown/.

164. Médecins Sans Frontières, MSF Reaction to '4-Day Lockdown' Plan, RELIEFWEB (Sept. 6, 2014), http://reliefweb.int/report/sierra-leone/msf-reaction-sierraleone-4-day-lockdown-plan.

165. Richard Schabas, Commentary, Severe Acute Respiratory Syndrome: Did Quarantine Help?, 15 Canadian J. Infectious Diseases \& Med. Microbiology 204 (2004).

166. Id.

167. Martin Cetron et al., Isolation and Quarantine: Containment Strategies for SARS 2003, in Learning from SARS: Preparing for the Next Disease OutBREAK: Workshop Summary 71, 74-75 (Stacey Knobler et al. eds., The National Academies Press 2004). 
tional quarantine practices, however, the very limited duration of Sierra Leone's three-day lockdown inherently limited its capacity to stymie the spread of EVD, which has a twenty-one-day incubation period.

In some ways, the lockdown replicated shelter-in-place orders used often during biological, chemical, and radiological incidents, and increasingly during security threats. Residents are asked to stay in their current locations until an all-clear order is issued, which may take hours or days. Shelter-in-place has been shown to be highly effective in reducing morbidity and mortality during chemical spills ${ }^{168}$ and active shooter events. ${ }^{169}$ Models show that its practice is also effective during a biological attack by preventing exposure to airborne biological agents. ${ }^{170}$ To the extent, however, that EVD already infiltrated populations in Sierra Leone, there is little chance that significant additional exposures via lockdown were thwarted. As well, only a small percentage of infected individuals could likely be identified during three days of lockdown. ${ }^{171}$

Shelter-in-place orders may severely restrict individual movement and prevent supplies reaching large institutions and residents within the cordon. ${ }^{172}$ Doctors Without Borders raised parallel concerns as the Sierra Leone lockdown went into effect, noting that many poor residents purchase food daily ${ }^{173}$ and get water from communal wells that would be inaccessible. ${ }^{174}$ Reports of public disdain arose when government workers did not have food to offer, ${ }^{175}$ nor any appropriate places to receive health services given by HCWs. ${ }^{176}$

House-to-house case identification and public education activities executed during Sierra Leone's lockdown resemble more traditional public health measures. For example, contact tracing has been used

168. Sheltering in Place as a Public Protective Action, NAT'L Inst. For Chemical STUdies 1, 46 (2001), http://www.nicsinfo.org/docs/shelter\%20in\%20place.pdf.

169. James G. Hodge, Jr. \& Kellie Nelson, Active Shooters in Health Care Settings: Prevention and Response Through Law and Policy, 42 J.L. Med. \& ETHICs 268, 269 (2014).

170. Lester L. Yuan, Sheltering Effects of Buildings from Biological Weapons, 8 SCI. \& Global Security 287, 310 (2000).

171. Whether officials achieved their goal of visiting every residence across the country is doubtful as pleas to extend the lockdown emerged to complete visits in urban areas. Sierra Leone Looks to Extend Ebola Lockdown as it Aims to Stop Spread, GuARDian (Sept. 21, 2014, 2:30 PM), http://www.theguardian.com/world/ 2014/sep/21/sierra-leone-freetown-lockdown-ebola-continues.

172. Nat'l Inst. For Chemical Studies, supra note 168, at 45.

173. Médecins Sans Frontières, supra note 164.

174. Poor Will Not Have Food or Water During Lockdown, Say Sierra Leoneans, Plan (Sept. 19, 2014), http://plan-international.org/about-plan/resources/mediacentre/press-releases/poor-will-not-have-food-or-water-during-lockdown-say-sierraleoneans/.

175. GuARdian, supra note 171.

176. Lisa O'Carroll, Sierra Leone's Planned Ebola Lockdown Could 'Spread Disease Further, GuARDiAn (Sept. 6, 2014, 4:40 AM), http://www.theguardian.com/world/ 2014/sep/06/sierra-leone-lockdown-ebola-outbreak. 
effectively in outbreaks to control the spread of infections in many scenarios. ${ }^{177}$ Effective public communication has been credited with maintaining calm in Toronto during SARS and increasing voluntary quarantine compliance. ${ }^{178}$ Strong public education campaigns are generally seen as keystone efforts in any infectious disease control program, whether preventive or responsive to an outbreak. ${ }^{179}$ Mass notifications through phone or email are frequently used in many disasters, and pilot projects have examined the utility of house-to-house visits for vulnerable populations. ${ }^{180}$ Subject to future findings, the education and sanitation components of the lockdown may have helped to improve the public's understanding of the spread of EVD and the need to seek health services.

During the Sierra Leone lockdown, 123 potential cases of EVD were identified. ${ }^{181}$ In addition, ninety-two bodies were removed for safe burial, ${ }^{182}$ reducing the potential for spread through unsafe funeral practices. There is little evidence, however, to suggest that these cases would not have been identified through other means in the same time period without a lockdown. Coupled with substantial hardships posed by lack of food, access to water, lost wages, and reduced economic activity, the utility of national or city-wide lockdowns during public health emergencies is seriously questioned. As a method of taking a public health inventory, the successes of Sierra Leone's national lockdown may be challenged when weighed against a bevy of deleterious impacts on the population, the great majority of which were not exposed to or infected with Ebola.

\section{Essence of Efficacy of Emergency Public Health Powers}

These brief case studies on isolation, border closure, and lockdown illustrate the complexities of assessing the efficacy of varied public health measures to control Ebola. When medical practitioners speak of efficacy of medical treatments, they refer to "the net health benefits

177. Don Klinkenberg et al., The Effectiveness of Contact Tracing in Emerging Epidemics, PLoS ONE (Dec. 20, 2006), http://www.plosone.org/article/ info \%3Adoi\%2F10.1371\%2Fjournal.pone.0000012; Fraser et al., supra note 117, at 6151.

178. Gene Matthews, Public Health Law Preparedness, in LeArning from SARS: Preparing for the Next Disease Outbreak: Workshop Summary 230 (2004).

179. See Addressing Communication Challenges During an Infectious Disease Emergency Response: State Experiences from the H1N1 Pandemic, Ass'N of STATE \& Territorial Health Officials, http://www.astho.org/Programs/Infectious-Disease/Addressing-Communication-Challenges-During-an-Infectious-Disease-Emergen cy-Response/ (last visited Nov. 11, 2014).

180. Sheri Fink, U.S. Mines Personal Health Data to Find the Vulnerable in Emergencies, N.Y. Times, May 16, 2014, at A18, available at http://www.nytimes.com/2014/ 05/16/us/us-mines-personal-health-data-to-aid-emergency-response.html?_r=2.

181. Bajekal, supra note 163.

182. Ebola outbreak: Sierra Leone lockdown not extended, CBC NEws (Sept. 21, 2014, 2:37 PM), http://www.cbc.ca/news/world/ebola-outbreak-sierra-leone-lockdownnot-extended-1.2773408. 
achievable under ideal conditions for carefully selected patients. . . . An efficacious treatment is one that does more good than harm to those who receive it." 183 Public health researchers refer to efficacy in terms of interventions for which "studies show the strongest association between the intervention and the [desired] outcome."184 "Efficacy," concludes one source, "is the ability to produce a desired amount of a desired effect." 185

To the degree that efficacy is tied solely to detection and prevention of the spread of Ebola, the practice of isolation offers a reasonable example of success. However, assessing efficacy of public health legal interventions tied solely to Ebola-related improvements is misguided. By this standard, isolation that prevents the spread of Ebola but kills the patient for unrelated reasons would be considered efficacious. Public health measures that mitigate one threat to communal health but raise multiple others are not efficacious from a public policy perspective.

The essence of efficacy for purposes of public health legal interventions is broader in scope. It requires balancing the underlying legal authority for the intervention, possible impairments of human rights, and potential negative collateral health impacts (akin to what economists might refer to as "opportunity costs"). ${ }^{186}$ Under this conception of efficacy, each of the public health interventions noted above presents a mixed bag of outcomes.

Touting the merits of isolation as a disease control measure cannot be divorced from the negative impacts on patients and their families coupled with the spotty record of actual compliance and infection avoidance among HCWs and others. Gauging the effectiveness of Ebola-related border closures seems speculative when similarly-situated countries apply the intervention unevenly or without adequate enforcement. Declaring victory following the administration of a national lockdown in Sierra Leone seems fallacious when balanced against significant, albeit temporary, infringements on the rights to health, travel, and access to food and water. ${ }^{187}$ If none of these public health legal measures meets our threshold of efficacy to control Ebola, maybe our balance needs to be recalibrated or our conception is merely flawed.

183. Wilhelm Kirch, The Encylcopedia of Public Health 321 (2008).

184. Rosanne P. Farris et al., Beyond Effectiveness: Evaluating the Public Health Impact of the WISEWOMAN Program, 97 Am. J. Pub. Health 641, 642 (2007).

185. KIRCH, supra note 183.

186. Opportunity cost is defined as "the most highly valued opportunity or alternative forfeited when a choice is made." Roger A. Arnold, Economics 5 (12th ed. 2015).

187. David Lewis, Sierra Leone Lockdown Will Not Help Halt Ebola, Reuters (Sept. 6, 2014, 12:23 PM), http://www.reuters.com/article/2014/09/06/us-health-ebolaidUSKBN0H10ID20140906. 
Yet, assessing the efficacy of these and other purported public health interventions consistent with our conception is critical. ${ }^{188}$ Public health officials may be authorized to use a litany of measures via emergency powers in principle, but if these choices lack effectiveness their use may be called into doubt for four essential reasons:

1. to the extent they infringe on human rights without justification they violate universal norms;

2. if these measures do not directly alleviate the impacts of Ebola while damaging populations in other ways, they cause more harm than good in contravention of ethical, legal, and human rights duties to protect the public's health;

3. absent sufficient assessment of their potential efficacy, these measures cannot be used reliably as tools to control infectious diseases; and

4. lacking reliability, their use may actually detract from other public health efforts to control Ebola.

So which emergency public health measures should be implemented when efficacy is unknown or uncertain and all other potential interventions are unavailable (e.g., vaccines, HCWs), impractical (e.g., removal of all West African patients to high-level treatment centers), or dysfunctional (e.g., active surveillance systems)? Why not let governments in Liberia, Sierra Leone, Guinea, and Nigeria experiment with a gamut of public health measures when no other good options exist? A similar question in a different context might ask whether to allow the use of experimental drugs for Ebola when half of infected patients are going to die anyway. What's the harm?

Minimal applications of experimental drugs can injure or kill patients. This is a regrettable consequence, but perhaps a risk that patients and practitioners are willing to take. Conversely, unproven use of alleged lawful public health interventions to control infectious disease outbreaks can destroy public trust and harm entire populations in contravention of legitimate public health practices grounded in science, not fiction. Balancing health and human rights requires solid data of an intervention's efficacy (or lack thereof). Such practices cannot reflect a respect for human rights when there is no clear, strong, and repeatable assessment of their capacity to improve the public's health. When the collective harms of disease control interventions infringe on human rights without public health justification, they not only lack efficacy, but also are unlawful as applied.

188. For an example of an efficacious public health intervention, see Fidel Villegas, et al., Administration of Triclabendazole Is Safe and Effective in Controlling Fascioliasis in an Endemic Community of the Bolivian Altiplano, 6 PLoS NeGLECTED Tropical Diseases 1 (2012) (triclabendazole is efficacious in treating endemic fascioliasis by reducing the intensity and prevalence of the illness). 


\section{Conclusion}

The spread of Ebola can be stopped, but how and at what price? Unwarranted uses of social distancing measures in affected West African countries may fail to control infectious diseases and negatively impact communal health by denying people access to food, medicines, treatments, and other life-sustaining services. There is a real potential that more persons may die from EVD in these regions due directly to deleterious public health practices applied across populations. More so, even greater numbers of persons may perish from causes other than EVD because public health interventions designed to halt the epidemic lack efficacy. To avoid these outcomes, public health powers must be tied to known outcomes across an array of communal health impacts. Humane, efficacious use of emergency public health powers coupled with major infusions of global resources and personnel may prevent excess morbidity and mortality from Ebola now, and for decades to come. 
Appendix 1. Ebola-related Emergency Measures in Select COUNTRIES

(NumericAl DATA AS OF 2/17/15)

\begin{tabular}{|c|c|c|c|c|}
\hline $\begin{array}{c}\text { Declaration } \\
\text { Information }\end{array}$ & Guinea & Liberia & Nigeria & Sierra Leone \\
\hline Date & $8 / 13 / 14$ & $8 / 6 / 14$ & $8 / 8 / 14$ & $7 / 30 / 14$ \\
\hline Duration & Indefinite & 99 days $^{1}$ & 6 months $^{2}$ & 60-90 days \\
\hline Type & $\begin{array}{l}\text { National Health } \\
\text { Emergency }^{3}\end{array}$ & $\begin{array}{c}\text { State of } \\
\text { Emergency }^{4}\end{array}$ & $\begin{array}{c}\text { National } \\
\text { Emergency }^{5}\end{array}$ & $\begin{array}{l}\text { State of Public } \\
\text { Emergency }\end{array}$ \\
\hline Declared By & $\begin{array}{l}\text { President Alpha } \\
\text { Condé }\end{array}$ & $\begin{array}{l}\text { President Ellen } \\
\text { Johnson Sirleaf }\end{array}$ & $\begin{array}{c}\text { President } \\
\text { Goodluck } \\
\text { Jonathan }\end{array}$ & $\begin{array}{c}\text { President Dr. } \\
\text { Ernest Bai } \\
\text { Koroma }\end{array}$ \\
\hline $\begin{array}{l}\text { Entity/Official } \\
\text { in Charge }\end{array}$ & $\begin{array}{c}\text { President Alpha } \\
\text { Condé }\end{array}$ & $\begin{array}{l}\text { President Ellen } \\
\text { Johnson Sirleaf } \\
\text { and Minister of } \\
\text { Internal Affairs }\end{array}$ & $\begin{array}{l}\text { Minister of } \\
\text { Health, } \\
\text { Professor } \\
\text { Onyebuchi } \\
\text { Chukwu }\end{array}$ & $\begin{array}{l}\text { Presidential } \\
\text { Task Force on } \\
\text { Ebola }\end{array}$ \\
\hline Affected \# $\mathrm{s}^{7}$ & $11,474,383$ & $4,092,310$ & $177,155,754$ & $5,743,725$ \\
\hline $\begin{array}{c}\text { Potential Cases/ } \\
\text { Deaths }{ }^{8}+\%\end{array}$ & $\begin{array}{c}3,044 / 1,995 \\
66 \% \text { death rate }\end{array}$ & $\begin{array}{c}8,881 / 3,826 \\
43 \% \text { death rate }\end{array}$ & $\begin{array}{c}20 / 8 \\
40 \% \text { death rate }\end{array}$ & $\begin{array}{c}10,934 / 3,341 \\
31 \% \text { death rate }\end{array}$ \\
\hline \multicolumn{5}{|l|}{$\begin{array}{c}\text { Emergency } \\
\text { Measures }\end{array}$} \\
\hline $\begin{array}{l}\text { Closures (borders, } \\
\text { schools, markets) }\end{array}$ & $\mathbf{\square}^{9}$ & $\mathbf{\square}^{10}$ & $\mathbf{\square}^{11}$ & $\mathbf{\square}^{12}$ \\
\hline $\begin{array}{c}\text { Compulsory } \\
\text { Leave }\end{array}$ & & - & & $\mathbf{\square}^{13}$ \\
\hline Cordon Sanitaire & $\mathbf{a}^{14}$ & $\mathbf{a}^{15}$ & & $\mathbf{a}^{16}$ \\
\hline Curfews & & $\mathbf{\square}^{17}$ & & $\mathbf{a}^{18}$ \\
\hline Disinfection & $\mathbf{q}^{19}$ & $\mathbf{a}^{20}$ & & $\mathbf{a}^{21}$ \\
\hline $\begin{array}{l}\text { Improved } \\
\text { Sanitation }\end{array}$ & $\mathbf{q}^{22}$ & - & & $\mathbf{\square}^{23}$ \\
\hline Isolation & $\mathbf{a}^{24}$ & $\mathbf{\square}^{25}$ & $\mathbf{a}^{26}$ & $\mathbf{a}^{27}$ \\
\hline Lockdown & & & & $\square^{28}$ \\
\hline Price Controls & & $\mathbf{q}^{29}$ & & \\
\hline Quarantine & $\mathbf{\square}^{30}$ & $\mathbf{a}^{31}$ & a & $\mathbf{a}^{32}$ \\
\hline Screening & $\mathbf{a}^{33}$ & $\mathbf{\square}^{34}$ & $\square$ & a \\
\hline Surveillance & 口 & 口 & a & 口 \\
\hline Testing & 口 & - & $\mathbf{a}^{35}$ & घ \\
\hline $\begin{array}{c}\text { Travel } \\
\text { Restrictions }\end{array}$ & - & - & - & घ \\
\hline Treatment & $\square$ & $\square$ & $\mathbf{m}^{36}$ & $\mathbf{a}^{37}$ \\
\hline Totals & 11 & 14 & 8 & 14 \\
\hline
\end{tabular}


1. On November 13, 2014, President Sirleaf opted not to extend the emergency declaration. Ellen Johnson Sirleaf, Statement Delivered by H. E. Ellen Johnson Sirleaf President of Liberia on the Lifting of the State of Emergency (Nov. 13, 2014), available at http://www.emansion.gov.lr/doc/State \%20of\%20Emergency\%20Speech $\% 20$ (Presedits).pdf.

2. Reuben Abati, President Jonathan Declares National Emergency on Ebola, Approves N1.9 Billion Special Intervention Fund, Reuben Abati (Aug. 8, 2014), http://www.reubenabati.com.ng/PRESIDENT-JONATHAN-DECLARES-NA-

TIONAL-EMERGENCY.html; see also CONSTITUTION OF NIGERIA 1999 § 305(6)(c), available at $\mathrm{http}: / / \mathrm{www} . w i p o . i n t / w i p o l e x / e n / t e x t . j s p ? f i l e \_i d=179202$.

3. See Guinea Declares Ebola a 'National Health Emergency, Agence FrancePresse (Aug. 13, 2014), Factiva, Doc. No. AFPR000020140813ea8d008c7; Fundamental Law of the Second Republic of Guinea [Constitution] 1990 § 74, available at http://www.chr.up.ac.za/images/files/documents/ahrdd/guinea/guinea_constitution _extract.pdf.

4. See Ellen Johnson Sirleaf, Statement on the Declaration of Emergency by President Ellen Johnson Sirleaf 2 (Aug. 6, 2014), available at http://www.emansion .gov.lr/doc/sdseg.pdf; Constitution of the Republic of Liberia 1986 § 86, available at http://www.liberianlegal.com/constitution1986.htm.

5. See Abati, supra note 2. See Constitution of Nigeria $1999 \S 305(6)(c)$, available at http://www.wipo.int/edocs/lexdocs/laws/en/ng/ng014en.pdf.

6. Ernest Bai Koroma, Address to the Nation on the Ebola Outbreak by His Excellency the President Dr. Ernest Bai Koroma (July 30, 2014), available at http:// www.statehouse.gov.sl/index.php/component/content/article/34-news-articles/925-ad dress-to-the-nation-on-the-ebola-outbreak-by-his-excellency-the-president-dr-ernestbai-koroma-july-30-2014 [hereinafter Address to the Nation]; Ernest Bai Koroma, Broadcast to the Nation on Further Measures to End the Ebola Outbreak by His Excellency the President Dr. Ernest Bai Koroma (Sept. 24, 2014), available at http:// www.statehouse.gov.sl/index.php/useful-links/1000-broadcast-to-the-nation-onfurther-measures-to-end-the-ebola-outbreak-by-his-excellency-the-president-dr-ernest-bai-koroma-september-24-2014 [hereinafter Broadcast to the Nation].

7. The World Factbook, U.S. Cent. InTELligence AgenCy, https://www.cia.gov/ library/publications/the-world-factbook/rankorder/2119rank.html (last visited Oct. 30, 2014).

8. Ebola Situation Report 11 February 2015, World Health Org. (Feb. 11, 2015), http://apps.who.int/ebola/en/ebola-situation-report/situation-reports/ebolasituation-report-11-february-2015.

9. Ellen Johnson Sirleaf et al., Joint Declaration of Heads of State and Government of the Mano River Union for the Eradication of Ebola in West Africa (Aug. 1, 2014), available at http://www.emansion.gov.lr/doc/MRU_EBOLA_jOINT.pdf.

10. Ellen Johnson Sirleaf, Special Statement by President Ellen Johnson Sirleaf on Additional Measures in the Fight Against the Ebola Virus Disease 1 (July 30, 2014), available at http://www.emansion.gov.lr/doc/Special_State_Delivered_July\%2030.pdf.

11. Nigeria, INT'L SOS, https://www.internationalsos.com/ebola/index.cfm?content _id=418\&language_id=ENG (last updated Jan. 19, 2015, 11:02 PM).

12. Fred Barbash, Sierra Leone Declares State of Emergency in Ebola Crisis, WAsH. Post (July 31, 2014), http://www.washingtonpost.com/news/morning-mix/wp/ 2014/07/31/sierra-leone-declares-state-of-emergency-in-ebola-crisis/.

13. See Address to the Nation, supra note 6.

14. Stephen Mihm, Fighting Ebola the Medieval Way, Bloomberg VIEW (Aug. 17, 2014, 10:53 AM), http://www.bloombergview.com/articles/2014-08-17/fightingebola-the-medieval-way.

15. Id.

16. Barbash, supra note 12.

17. Ebola Crisis: Liberia Orders Curfew and Quarantine, BBC News Afr. (Aug. 19, 2014, 11:44 PM), http://www.bbc.com/news/world-africa-28862591.

18. Broadcast to the Nation, supra note 6. 
19. Ebola: Guineans Riot in Nzerekore Over Disinfectant, BBC News Afr. (Aug. 29, 2014, 8:46 PM), http://www.bbc.com/news/world-africa-28984259.

20. Sirleaf, supra note 10.

21. Ebola Emergency, Medecins Sans Frontieres, http://www.msf.org.uk/article/ebola-hygiene-workers-in-bo-sierra-leone-are-on-the-front-line (last visited Nov. 17, 2014).

22. Ebola: 5 Tips to Avoid the Deadly Disease, INT'L SOS, https://plan-internation al.org/about-plan/resources/news/ebola-outbreak-5-tips-to-avoid-the-deadly-disease/ (last visited Nov. 17, 2014).

23. Id.

24. Sirleaf et al., supra note 9 , at 2 .

25. $I d$.

26. Onyebuchi Chukwu, Minister of Health, Fed. Republic of Nigeria, Text of the Statement by Minister of Health, Professor Onyebuchi Chukwu on the Strategies of Government to Prevent Spread of Ebola Virus Disease (EVD) (Aug. 11, 2014), available at http://www.nigeria.gov.ng/2012-10-29-11-09-25/speeches-and-statements/1187text-of-the-statement-by-the-minister-of-health-professor-onyebuchi-chukwu-on-thestrategies-of-government-to-prevent-spread-of-ebola-virus-disease-evd-at-the-emer gency-national-council-on-health-.

27. Sierra Leone, INT'L SOS, https://www.internationalsos.com/ebola/index.cfm? content_id=397\&language_id=ENG (last visited Sept. 10, 2014).

28. Sierra Leone Declares Ebola Lockdown, BBC News AFr. (Sept. 6, 2014, 8:23 AM), http://www.bbc.com/news/world-africa-29093048.

29. James Butty, Liberia Vows to Control Ebola-Related Price Hikes, VoICE of Am. (Aug. 20, 2014, 1:21 AM), http://www.voanews.com/content/liberia-vows-to-control-ebola-related-price-hikes/2419520.html.

30. Boubacar Diallo \& Krista Larson, Ebola Victims Quarantined in Guinea, Associated Press (Mar. 25, 2014, 3:13 PM), http://bigstory.ap.org/article/teams-quaran tine-victims-guinea-ebola-outbreak.

31. Sirleaf, supra note 10.

32. Barbash, supra note 12.

33. Sirleaf et al., supra note 9 , at 3.

34. $I d$.

35. INT'L SOS, supra note 11.

36. Chukwu, supra note 26.

37. INT'L SOS, supra note 27. 